\title{
MUSYÂRAKAH: ANTARA FIKIH DAN PERBANKAN SYARIAH
}

\author{
Sirajul Arifin \\ Fakultas Syariah IAIN Sunan Ampel \\ Jl. Jendral Ahmad Yani No. 117, Surabaya, 60237 \\ e-mail: sirajul.arifin@yahoo.com
}

\begin{abstract}
Abstrak: Musyârakah merupakan salah satu model profit and lost-sharing (PLS) yang kehadirannya dalam bank syari'ah paralel dengan Islam. Musyârakah dalam praktik perbankan syariah tidak dikonstruk melalui fikih an sich, tetapi telah diadaptasikan dengan situasi dan kondisi riil yang didasarkan pada fikih lokal kekinian, $\mathrm{KHI}$ atau fatwa MUI. Dalam fikih klasik, ulama sepakat bahwa jaminan, misalnya, tidak perlu mewujud dalam kontrak musyârakah, karena mitra adalah orang yang dipercaya, dan atas dasar "kepercayaan" ini, maka mitra yang satu tidak dapat menuntut jaminan dari mitra yang lain. Namun fikih lokal memberikan kelonggaran kepada bank syariah mensyaratkan mitranya untuk memberikan jaminan guna mereduksi risiko dalam pembiayaan musyârakah.
\end{abstract}

\begin{abstract}
Musyârakah: Between fiqh and Syariah banking. Musyârakah is one of the profit and lost-sharing (PLS) models which is parallel with Islamic bank concept. At the practical level of syariah banking, musyârakah is not purely legal construction but it is a social adaptation to the real circumstances which are based on contemporary local fiqh (Islamic law). Classical fiq $h$ does not require the guarantee to be embodied in a musyârakah contract, because the partner is a trustworthy person. Moreover, on the basis of trust, one partner cannot require a guarantee from the other party. Otherwise, local fiqh gives concessions to Islamic bank, i.e., it requires partners to provide assurance in order to reduce risk in the musyârakah financing.
\end{abstract}

Kata Kunci: musyârakah, bagi hasil, fikih muamalah, bank syari'ah

\section{Pendahuluan}

Sejak awal, fikih dianggap mampu berdialog dengan zaman, ${ }^{1}$ karena karakter genuine

${ }^{1}$ Farhad Nomani and Ali Rahnema, Islamic Economic Systems (London \& New Jersey: Zed Books Ltd., 1994), h. 1. 
fikih yang elastis dan fleksibel, ${ }^{2}$ sehingga fikih dipandang otoritatif dalam menyelesaikan persoalan umat. Dalam konteks ini, peran fikih tidak dapat dilihat sebelah mata. Ia tetap menjadi faktor determinan yang ikut serta menentukan perjalanan sejarah kemanusiaan umat Islam. Bahkan dalam muamalah, ranah fikih begitu cepat untuk semestinya mengikuti peradaban manusia dalam, misalnya, berbagai bentuk transaksi dengan segala variannya. Ini berbeda dengan wilayah ibadah mahdhah, yang sama sekali tidak diperkenankan mempertanyakan, mengotak-atik atau bahkan melakukan gugatan kritis atasnya.

Hal ini karena ranah ibadah diklaim sebagai ghayr ma'qûl al-ma'nâ di mana sama sekali tidak menyediakan ruang dialog di dalamnya. Tentu saja, ini sangat berbeda dengan ranah muamalah yang ma'qûl al-ma'nâ. Salah satu lingkup muamalah adalah perbankan berbasis syariah, ${ }^{3}$ yang hingga kini terus mewacana dan tetap urgen untuk dikaji. Secara de facto, kehadiran bank syariah sejak tahun 70-an ${ }^{4}$ sedemikian menggoncang tata sosialekonomi dunia. Yang tergoncang adalah tata ekonomi kapitalis yang telah membumi, khususnya bank-bank konvensional yang selama ini menginduk pada sistem ekonomi tersebut. Karena itu pun, asumsi (para akademisi) Barat bahwa bank tanpa bunga adalah tidakmungkin, berguguran. Kenyataannya, bank syariah tidak hanya mampu survive dan bertahan hidup, tetapi juga memberikan alternatif solusi atas berbagai persoalan akut bank konvensional-kapitalistik.

Karena itu, pemunculan bank syariah, tak pelak, selain merupakan respons atas ketidak berdayaan bank-bank konvensional dalam memberikan kesejahteraan bagi manusia, juga karena bank konvensional dipandang gagal mendistribusikan kekayaan secara adil dan merata ke seluruh lapisan masyarakat. Bank konvensional hanya mementingkan segelintir pemilik modal yang selalu diuntungkan dengan sistem bunga. Dalam kondisi inilah, bank

${ }^{2}$ M. Th. Houtsma, et al., E.J. Brill's First Encyclopaedia of Islam 1913-1936, Vol. III (Leiden: E.J. Brill, 1987), h. 101; M. Abdul Mujieb et al., Kamus Istilah Fikih (Jakarta: Pustaka Firdaus, 1994), h. 77-78.

${ }^{3}$ Pada mulanya, terma syarî́ah digunakan untuk "jalan ke sumber (mata) air dan tempat orangorang minum". Orang-orang Arab, kala itu, menggunakan kata tersebut untuk suatu nama atau sebutan bagi jalan setapak yang menuju ke palung air dengan tanda yang jelas, sehingga kelihatan oleh orang-oarng yang membutuhkan air sekalipun dari jarak jauh. Pengertian lain dari kata syarîa $h$ ialah "jalan yang lurus" (al-tharîqah al-mustaqîmah), yaitu jalan yang dengan mudah dapat mengantarkan seseorang ke tempat tujuan. Dalam perkembangan selanjutnya, istilah syarî́ah oleh para ulama' dipergunakan untuk pengertian "segala aturan" yang ditentukan Allah untuk para hamba-Nya, baik yang berkenaan dengan persoalan akidah maupun yang bertalian dengan masalah-masalah hukum. Aturan-aturan yang telah ditetapkan Allah itulah-kemudiam-dinamai syarî́ah, karena pada umumnya bersifat tegas dan jelas, sehingga mudah dimengerti dan diikuti bagaikan jalan raya (tol) yang mulus tanpa ada tikungan dan simpangan. Dengan demikian, ketika istilah "syarî́ah" bergandengan dengan kata "perbankan", maka perbankan syari‘ah merupakan perbankan yang operasionalnya didasarkan pada aturan-aturan yang telah ditentukan oleh Allah. Lihat Harun Nasution (ed.), Ensiklopedi Islam Indonesia (Jakarta: Djambatan, 1992), h. 896-897. Lihat juga Cyril Glasse, the Concise Encyclopedia of Islam (London: Stacy International, 1989), h. 361-362; Said Ramadan, Islamic Law: the Scope and Equity (Malaysia: Muslim Youth Movement of Malaysia, 1992), h. 42-51.

${ }^{4}$ Muhammad Nejatullah Siddiqi, "Islamic Approaches to Money, Banking and Monetary: a Review," dalam Muhammad Ariff (ed.), Monetary and Fiscal Economics of Islam (Jeddah: International Centre for Research in Islamic Economics, 1982), h. 30. 
syariah lahir. Karena itu, pemunculannya juga dengan agenda-agenda besar yang tidak tertangani oleh bank-bank konvensional. Yang paling penting adalah bahwa kehadiran bank syariah dilatari oleh realitas sosial bahwa umat Islam berkehendak untuk bermuamalah secara islami.

Bermuamalah secara islami berarti juga menolak sistem bunga yang terdapat dalam bank konvensional. Sistem bunga tidak diberi tempat dalam bank syariah, ${ }^{5}$ karena, menurut jumhur ulama, bunga bank hukumnya haram ${ }^{6}$ atau paling tidak, merupakan barang syubhat yang semestinya dijauhi dan dihindari. Untuk menghindari praktik bunga yang identik dengan riba dan dilarang ini, ${ }^{7}$ jalan satu-satunya adalah mendirikan bank yang pola transaksinya berbasis syariah. ${ }^{8}$ Dalam bank syariah, pola transaksi yang dibangun antara lain didasarkan pada profit and lost-sharing (selanjutnya disebut PLS). ${ }^{9}$

Musyârakah merupakah salah satu diantara dua model PLS yang kehadirannya

${ }^{5}$ M. Uzair, an Outline of Interest-Free Banking (Karachi: Royal Book Company, 1978), h. 75.

${ }^{6}$ Syed Nawab Haider Naqvi, Ethics and Economics: An Islamic Systems (U.K.: The Islamic Foundation, t.t.), h. 110-112.

${ }^{7}$ Mohammad Manzoor Alam, dalam Perspectives on Islamic Economics, mengungkap tiga alasan pelarangan bunga. Ia mengatakan, "the following points are important to understand why Islam has abolished interest; a) interest involves both oppression (zhulm) and exploitation, b) interest transfers wealth from the poor to the rich, increasing inequality in the distribution of wealth, and c) yet, another reason for the prohibiton of interest is that it creats on idle class of people who receive their income from accumulated wealth. Lihat Mohammad Manzoor Alam, Perspectives on Islamic Economics (New Delhi: Institute of Objective Studies, 1996), h. 70-71. Pelarangan bunga (yang diklaim termasuk riba), misalnya dalam perbankan syariah, berarti bunga tidak memiliki tempat dalam perbankan tersebut. Hilangnya bunga (riba) dan hadirnya pola bagi hasil adalah dipulihkannya akses golongan masyarakat lemah terhadap modal, karena mereka dapat bermitra dalam berbagai usaha. Ini berarti kesempatan bagi golongan ekonomi lemah untuk ikut memiliki alat produksi dan atau menjalankan sendiri usahanya kembali dibuka. Atau, jika usaha sendiri tidak dimungkinkan, misalnya karena alasan keahlian atau minat, mereka bisa menawarkan tenaganya kepada orang lain tanpa harus menjadi korban eksploitatif oleh institusi ribawi. Sebaliknya, institusi keuangan non-ribawi juga tidak perlu harus merugi. Memang, dalam sistem ekonomi non-riba ini bank tidak berhak mengeruk untung, tapi harus bisa berkembang sebagai lembaga sosial atau bayt al-mâl atas tanggungan masyarakat seluruhnya, baik sebagai penyimpan maupun peminjam. Karena, keberadaannya memang semestinya merupakan kepentingan bagi semua. Yang punya uang berkepentingan dengan bank non-riba karena dengan jasanya ia bisa menyimpan uangnya dengan jaminan inflasi dan sekaligus pengamanan dari kemungkinan pencuri. Bahkan, jika yang bersangkutan, sebagai deposan, adalah orang yang terpanggil oleh anjuran al-Qur'an, maka keuntungan lain yang tidak kalah besarnya adalah bahwa dengan lembaga bank tersebut, di satu pihak, mereka dapat mentasarrufkan (meminjamkan) uangnya kepada orang lain secara terjamin, dan di pihak lain, dapat terhindar dari ancaman Tuhan atas orang-orang yang gemar menyimpan kekayaan dengan memutuskan fungsi sosialnya.

${ }^{8} \mathrm{M}$. Fahim Khan, Essays in Islamic Economics (Leicester, UK: the Islamic Foundation, 1995), h. 77-78.

${ }^{9}$ S.H. Shiddiqi, Islamic Banking: Genesis, Rationale, Evaluation and Review, Prospects and Challenges (Karachi: Royal Book Company, 1994), h. 28. Lihat juga Muhammad Akram Khan, An Introduction to Islamic Economics (Islamabad: International Institute of Islamic Thought, 1994), h. 13-14; Anwar Iqbal Qureshi, Islam and the Theory of Interest (Lahore: Sh. Mhd. Ashraf, 1991), h. 27. 
dalam bank syariah tidak bertentangan bahkan disukai oleh Islam. ${ }^{10}$ Namun demikian, apakah konstruk musyârakah dalam praktik perbankan syariah berangkat dari konsep fikih klasik an sich dan tidak melalui adaptasi dengan fikih kekinian. Karenanya, dalam artikel ini berusaha mengeksplorasi konsep musyârakah dan berbagai variannya baik dalam patron fikih maupun dalam praktik perbankan syariah.

\title{
Legal Syar'î Entitas Musyârakah
}

Musyârakah, yang dalam kitab-kitab fikih kental dengan sebutan syirkah atau syarikah, ${ }^{11}$

\begin{abstract}
${ }^{10}$ Dua model profit and loss-sharing (selanjutnya disebut PLS) adalah mudhârabah dan musyârakah. Namun diantara dua model ini, mudhârabah tergolong sebagai model yang paling umum digunakan, minimal dari aspek peningkatan dana. Bahkan dalam buku terjemahan berjudul Perbankan Syari'ah: Prinsip, Praktek dan Prospek, Lewis dan Algaoud memberikan penekanan dengan sebuah catatan bahwa meskipun PLS merupakan gambaran yang paling umum digunakan untuk model pendanaan Islam, namun ia tidak murni "bagi rugi" (lost sharing) dilihat dalam perspektif ekonomi, karena si pemilik modal adalah mitra yang kehilangan modal, sementara yang lain hanya kehilangan usahanya. Penjelasan ini dapat dilihat dalam Mervyn K. Lewis dan Latifa M. Algaoud, Perbankan Syari'ah: Prinsip, Praktek dan Prospek, terj. Burhan Wirasubrata (Jakarta: Serambi Ilmu Semesta, 2003), h. 65.

${ }^{11}$ Variasi istilah yang representatif untuk merujuk istilah musyârakah juga disebutkan oleh al-Syawkânî. Dalam Nayl al-Awthâr, ia mengatakan bahwa istilah musyârakah sering dirujuk oleh dua kata yang berbeda, yaitu kata syirkah (bi kasr al-syîn wa sukûn al-râ') dan kata syarikah (bi fath al-syîn wa kasr al-râ'). Lihat Muhammad bin 'Alî bin Muhammad alSyawkânî, Nayl al-Awthâr: Syarh Muntaqâ al-Akhbâr min Ahâdîts al-Akhyâr, Juz V (Beirut: Dâr al-Jîl, t.t.), h. 264. Makna syirkah atau syarikah, dan kemudian dalam bentuk jamaknya adalah syarikât, berarti perusahaan bersama, asosiasi, persekutuan dan perseroan. Pemaknaan ini dapat dilihat dalam Atabik Ali dan Ahmad Zuhdi Muhdor, Kamus Kontemporer Arab-Indonesia (Yogyakarta: Multi Karya Grafika, 2001), h. 1129-1130. Lihat juga arti kata syirkah dalam Muhammad Syafi'i Antonio, Bank Syari'ah: dari Teori ke Praktek (Jakarta: Gema Insani Press, 2001), h. 90; Afzalur Rahman, Economic Doctrines of Islam, terj. Suroyo dan Nastangin, Jilid IV (Yogyakarta: Dana Bakti Wakaf, 1996), h. 365.

${ }^{12}$ Kata syaraka dalam al-Qur'an disebut sebanyak 170 kali, walaupun tidak secara jelas menunjukkan pengertian "kerja sama" dalam dunia bisnis. Namun akan dapat dipahami dengan makna "kerja sama" jika melihat keterangan dari Nabi, sahabat dan para ulama yang menyatakan keabsahan musyârakah untuk dilakukan dalam dunia bisnis. Lihat keterangan ini dalam Abdullah Saeed, Bank Islam dan Bunga: Studi Kritis dan Interpretasi Kontemporer tentang Riba dan Bunga (Yogyakarta: Pustaka Pelajar, 2003), h. 106-107.

${ }^{13}$ Makna kata tersebut sama dengan makna yang dikonstruk oleh al-Khayyâth. Ia memaknai syirkah dengan ikhtilâth (percampuran), baik percampuran "dua orang" maupun percampuran dua harta, "harta" seseorang dengan "harta" orang lain, ${ }^{14}$ bahkan Alî Fikrî mengandaikan percampuran laiknya dua unsur senyawa yang sulit dan absurd untuk dibedakan. Lihat 'Alî Fikrî, al-Mu 'âmalât al-Mâdiyah wa al-Adabîyah, Jilid I (Kairo: Mushtafâ al-Bâb al-Halibî, t.t.), h. 204. Pemaknaan ikhtilâth yang demikian, menurut al-Khayyâth, bukan tanpa dasar, melainkan didasarkan pada dua sumber yang berbeda, yaitu percampuran yang pertama didasarkan pada pandangan Muhammad 'Alâ' al-Dîn dalam karyanya, Al-Dâr al-Muntaqâ: Syarh Multaqâ al-Abharar, sedangkan percampuran yang kedua dan terakhir dikutip dari Lisân al-'Arab karya Ibn Manzhûr. Istilah syirkah, kata al-Khayyâth, dalam pengertian lughawî memang bersumber dari beberapa hadis, antara lain; hadis "al-nâs syurakầ fí tsalâts al-mâ' wa al-kalâ' wa al-nâr", hadis Mu'âdz "annahu
\end{abstract}


secara bahasa berasal dari kata kerja syaraka ${ }^{12}$ yang berarti mencampur sesuatu dengan erat. ${ }^{13}$ Sedangkan dalam pengertian ishthilâhî, para ulama fikih memberikan definisi syirkah dengan redaksi yang berbeda-beda. Ulama mazhab Maliki mendefinisikan syirkah sebagai "suatu izin untuk bertindak secara hukum bagi dua orang yang bekerja sama terhadap harta mereka". Bagi Syafiiyah, syirkah adalah "adanya hak bertindak secara hukum bagi dua orang atau lebih terhadap sesuatu yang mereka sepakati". Menurut Hanafiyah, syirkah merupakan "akad yang dilakukan oleh orang yang bekerja sama dalam modal dan keuntungan". Sedangkan Hanabilah medefinisikannya dengan "hak (wewenang) atau pengolahan harta". ${ }^{14}$ Dengan demikian, walaupun definisi para ulama itu secara redaksional berbeda, namun secara substansial kata syirkah merujuk makna yang sama, yaitu suatu ikatan kerja sama yang dilakukan oleh dua orang atau lebih dalam dunia bisnis.

Musyârakah yang berasal dari akar kata sy-r-k-meskipun tidak satupun dari bentuk tersebut yang secara jelas menunjukkan pengertian "kerja sama" dalam dunia bisnissangat paralel dengan nilai-nilai yang terkandung dalam al-Qur'an, beberapa keterangan dari nabi baik yang mewujud dalam tradisi lisan maupun tulisan, penjelasan para sahabat, dan konsesi ulama yang mengamini keabsahan musyârakah untuk dilaksanakan dalam dunia bisnis.

Dalam al-Qur'an, konsep musyârakah didasari oleh firman Allah dalam surat al-Nisâ'/ 4: 12, "...maka mereka bersekutu dalam sepertiga harta". ${ }^{15}$ Dalam ayat ini Allah mengafirmasi kerja sama berbagai pihak (syurakâ') dalam sepertiga harta yang dimiliki. Selain ayat tersebut, Allah juga memperkuat keberadaan musyârakah melalui firman-Nya dalam surat Shâd ayat 24, “...sesungguhnya kebanyakan dari orang-orang yang berserikat itu sebagian mereka berbuat zalim kepada sebagian yang lain, kecuali orang-orang yang beriman dan mengerjakan amal-amal saleh". ${ }^{16}$ Dalam surat ini Allah mengakui adanya kerja sama dalam kepemilikan sebagai implikasi dari transaksi yang dibangun. Pengakuan ini semakian kuat dan nyata ketika secara jelas Sayyid Sabiqjuga mengungkap makna kata al-khulathâ'. Menurutnya, kata al-khulathâ' mengandung artial-syurakâ', yakni "mereka yang berserikat (bekerja sama)". ${ }^{17}$

Selain al-Qur'an, hadis Qudsi pun melegitimasi konsep musyârakah tersebut. Matan

ajâz bayna ahl al-Yaman al-syirk ay al-ikhtilâth fì al-ardh", hadis 'Umar bin 'Abd al-Azîz "anna alsyirk jầiz ay al-isytirâk", hadis "Umar bin 'Abd al-Azîz "anna al-syirk jầ'iz ay al-isytirâk", dan hadis Umm Ma'bad "tusyârikna hazlî mukhhunna qalîl ay ammuhunna al-hazâl fa isytarakna fỉh". Dari konsepsi di atas jelas bahwa syirkah memiliki dua makna lughawî, yaitu; pertama, percampuran (al-khalth) secara mutlak baik dalam harta, orang, atau selain keduanya, dan kedua, kontrak (al-`aqd). Lihat al-Khayyâth, al-Syarikât, h. 23.

${ }^{14}$ Wahbah al-Zuhaylî, al-Fikih al-Islâmî wa Adillatuh, Juz IV (Kairo: Dâr al-Fikr, 1989), h. 792793. Lihat juga dalam Muhammad bin Ibrâhîm al-Mûsâ, Syarikât al-Asykhâsh bayna al-Syarî́ah wa al-Qânûn (t.t.p.: Jâmi'ah al-Imâm Muhammad bin Mas'ûd al-Islâmîyah, 1401 H.), h. 23-24.

${ }^{15}$ Q.S. al-Nisâ'/4: 12.

${ }^{16}$ Q.S. Shâd/38: 24.

${ }^{17}$ Sayyid Sabiq, Fikih al-Sunnah, Jilid III (Kairo: Dâr al-Fath li al-Il'âm al-Aarabî, 2000), h. 202. 
hadis "inna Allâh yaqûl: anâ tsâlits al-syarîkayn mâ lam yakhun ahaduhumâ shâhibah faidhâ khânah kharajtu min baynihimâ" menunjukkan pengakuan Allah akan adanya musyârakah, karena menurut hadis ini, Allah menjaga dan memberkahi harta orang-orang yang melakukan musyârakah selama salah satu pihak yang terlibat dalam syirkah tidak berkhianat.

Para ulama juga sangat apresiatif dan bahkan sepakat terhadap legitimasi musyârakah, walaupun dalam beberapa bagian, mereka berbeda pandangan. Kesepakatan akan konsep musyârakah yang demikian merupakan sebuah dukungan kuat bagi terwujudnya kesejahteraan (falâh) umat. Kesejahteraan yang dicitakan Islam merupakan wujud konkret dari tujuan syariah (maqâshid al-syarî‘ah). Tujuan syariah, sebagaimana yang dieksplorasi oleh alGhazâlî, mencakup segala sesuatu yang dianggap perlu untuk melindungi dan memperkaya iman, kehidupan, akal, keturunan dan harta benda. Al-Ghazâlî meletakkan dasar iman pada deretan awal, karena dalam Islam, iman menjadi unsur dominan dalam mengkonstruk kesejahteraan yang berkeseimbangan. Iman meletakkan hubungan manusia pada suatu_dasar yang tepat dan memungkinkan manusia dapat berinteraksi (musyârakah) dengan sesamanya dalam suatu sikap yang seimbang. Iman juga menjadi garda moral untuk mengalokasikan dan mendistribusikan sumber daya sesuai dengan tata atur persaudaraan dan keadilan sosioekonomi, bahkan menjadi suatu sistem motivasi yang memberikan kekuatan yang mengarah pada tujuan pemenuhan kebutuhan dan distribusi pendapatan dan kekayaan yang adil.

Selain itu, harta benda al-Ghazâlî letakkan dalam bagian akhir, karena harta bukan merupakan tujuan itu sendiri. Meskipun sangat penting dan pokok untuk merealisasikan kesejahteraan manusia, namun harta hanya sebuah alat. Harta tidak dapat mewujudkan tujuan ini kecuali dialokasikan secara efisien dan didistribusikan secara adil. Hal ini menuntut keterlibatan moral (iman) dalam pencarian harta dan pengoperasian pasar. Di sinilah konsep musyârakah sebagai sebuah konsep yang menjunjung nilai-nilai kesalihan syariah dalam membangun kesejahteraan manusia.

\section{Musyârakah dalam Patron Fikih}

Dalam al-Qur'an, kata musyârakah, yang merupakan dasar kedua dari konsep PLS setelah mudhârabah, memang tidak secara nyata merujuk pada makna kemitraan dalam suatu ikatan bisnis. Namun ketika didasarkan pada sejumlah ayat al-Qur'an, terutama dua ayat dalam surat di atas, maupun sejumlah riwayat yang dinisbatkan kepada Nabi dan para sahabat, maka kemudian para ulama sepakat untuk melegitimasi keabsahan musyârakah dalam ikatan bisnis. Konsep, bentuk, rukun, syarat dan berbagai variannya yang secara detail terurai dalam kajian fikih merupakan kreasi ijtihadi para ahli fikih. ${ }^{18}$ Keran ijtihadi terhadap

${ }^{18}$ Beberapa pernyataan yang dinisbatkan kepada para sahabat menunjukkan bahwa beberapa bentuk kemitraan memang pernah dilakukan oleh generasi Muslim awal. Pernyataan-pernyataan itu hanya mengindikasikan eksistensi suatu bentuk kemintraan, tanpa menunjukkan istilahistilah, syarat-syarat atau konsep apa pun yang bisa dikaitkan dengan kemitraan ini. Berangkat dari kenyataan bahwa riwayat-riwayat itu tidak memberikan sedikit pun keterangan mengenai 
persoalan musyârakah memang terbuka lebar mengingat musyârakah merupakan salah satu elemen muamalah yang diklaim sebagai ma'qûl al-ma'nâ.

Pertama, bentuk-bentuk musyârakah. Musyârakah, atau dalam fikih dikenal dengan istilah syirkah, pada dasarnya dibagi ke dalam dua kategori, yaitu syirkah al-amlâk dan syirkah al-'uqûd. ${ }^{19}$ Syirkah al-amlâk merupakan kerja sama dalam kepemilikan barang dimana dua orang atau lebih secara bersama-sama memiliki suatu barang tanpa melalui akad syirkah terlebih dahulu. ${ }^{20}$ Syirkah dalam kategori ini juga terbagi dua macam, yaitu pertama, syirkah jabrîyah. Syirkah jenis pertama ini terjadi secara otomatis, namun tidak ada peluang untuk memilih dan harus melalui paksaan. Otomatis berarti tidak memerlukan kontrak untuk mengkonstruknya, dan harus dipaksa, karena tidak ada opsi untuk menolaknya dan bukan atas kehendak orang yang berserikat. ${ }^{21}$ Syirkah ini terjadi pada harta warisan, hibah dan wasiat. Misalnya, a) jika dua saudara memperoleh harta warisan dari orangtuanya, maka harta tersebut menjadi harta syirkah dan menjadi milik mereka berdua, sekalipun tanpa ada usaha untuk mendapatkannya, b) jika dua orang mendapatkan hibah dari orang lain, maka barang hibah tersebut menjadi milik mereka, walaupun tidak ada upaya untuk mendapatkan barang tersebut, atau c) jika dua orang mendapatkan wasiat dari seseorang berupa sebuah rumah, maka rumah tersebut merupakan milik kedua penerima wasiat, walaupun tanpa ada usaha untuk memperolehnya.

Sedangkan syirkah al-amlâk model kedua adalah syirkah ikhtiyârîyah. Syirkah jenis ini berbeda dengan jenis syirkah yang pertama. Syirkah ini tidak terjadi secara otomatis, tetapi bebas pilih. Tidak otomatis berarti kedua belah pihak masih memerlukan kesepakatan untuk membentuknya, dan bebas pilih berarti ada pilihan untuk menolak, karena, syirkah ini dibangun atas kehendak dan usaha (ikhtiyâr) mereka yang berserikat. Seperti dua orang memiliki suatu barang yang mereka bayar berdua, maka barang tersebut menjadi milik mereka dan merupakan harta syirkah, misalnya a) jika dua orang atau lebih bersepakat untuk menyewa sebuah komputer untuk dipakai secara bersama-sama, maka barang tersebut merupakan barang syirkah. Keduanya mempunyai hak untuk menggunakan barang tersebut selama jangka waktu tertentu, b) jika dua orang atau lebih membeli suatu barang secara bersama-sama, maka barang tersebut merupakan barang syirkah. Keduanya berhak menggunakan barang tersebut karena milik bersama.

Dalam syirkah al-amlâk, salah satu pihak tidak berhak bertindak dalam penggunaan barang syirkah tanpa izin dari pihak lainnya karena masing-masing pihak terikat dengan

definisi dan syarat-syarat yang sahih dari kontrak kemitraan semisal yang kemudian dikenal dalam fikih, maka definisi dan syarat-syarat yang sedemikian rupa diuraikan secara detail dalam fikih merupakan produk ijtihad para ulama fikih.

${ }^{19}$ Sâbiq, Fiqh al-Sunnah, h. 202. Lihat juga A.A. Islahi, Konsep Ekonomi Ibnu Taimiyah, terj. Anshari Thayib (Surabaya: Bina Ilmu, 1997), h. 194.

${ }^{20}$ Sâbiq, Fiqh al-Sunnah, h. 202.

${ }^{21}$ Ibid., h. 202-203. 
perjanjian kerja sama atau bergabung dalam suatu kepentingan harta, dan terbentuknya syirkah tersebut untuk memperoleh keuntungan dalam bentuk harta benda. ${ }^{22}$ Selain syirkah al-amlâk, terdapat bentuk syirkah yang lain, yaitu syirkah al-uqûd. Syirkah ini dapat dianggap sebagai kemitraan yang sesungguhnya, karena para pihak yang berserikat secara sukarela berkeinginan untuk membuat suatu perjanjian investasi bersama dan berbagi untung dan rugi. Perjanjian yang dimaksud tidak perlu merupakan suatu perjanjian yang formal dan tertulis. Perjanjian itu bisa saja informal dan secara lisan. Tetapi, sebagaimana halnya dalam perjanjian mudhârabah, adalah lebih baik, bahkan bagi saya menjadi suatu keharusan, jika perjanjian syirkah al-'uqûd diformalkan dalam suatu perjanjian tertulis dengan disaksikan oleh para saksi yang memenuhi syarat sesuai dengan ketentuan al-Qur'an tentang pinjaman dan transaksi-transaksi bisnis yang penting. ${ }^{23}$

Namun demikian, para ulama berbeda pandangan dalam mempersepsikan bentuk syirkah yang kedua ini. Ulama mazhab Hanbali berpandangan bahwa syirkah al-'uqûd dibagi menjadi lima bentuk syirkah, meliputi; syirkah al-inân, syirkah al-abdân, syirkah al-wujûh, syirkah al-mufâwadhah, dan syirkah al-mudhârabah. Sedangkan ulama fikih Mesir, di antaranya Malikiyah dan Syafi iyah, hanya mengapresiasi empat dari lima bentuk syirkah yang ditawarkan oleh ulama mazhab Hanbali, kecuali syirkah al-mudhârabah. Menurutnya, mudhârabah bukan tergolong sebagai syirkah. ${ }^{24}$ Berbeda dengan ketiga mazhab di atas, ulama mazhab Hanafi justru hanya melegitimasi tiga bentuk syirkah yang mencakup syirkah al-amwâl, syirkah al-a ' mâl, dan syirkah al-wujûh. Ketiga bentuk syirkah ini, menurut mazhab Hanafi, bisa tergolong dan digolongkan dalam kategori 'inân dan mufâwadhah.

Ulama fikih sepakat bahwa keberadaan syirkah al-'inân dibenarkan dalam Islam. ${ }^{25}$ Syirkah al-inân adalah suatu perjanjian kemitraan di mana dua mitra atau lebih memberikan modal, dan keuntungannya dibagi sesuai kesepakatan. ${ }^{26}$ Dalam syirkah ini, modal dan tanggung jawab yang digabungkan masing-masing pihak tidak harus berjumlah sama. Pembiayaan dalam syirkah ini memang lazimnya disediakan oleh kedua belah pihak, namun salah satu pihak dimungkinkan menyediakan prosentase lebih banyak daripada pihak lain. Dalam fikih, kebebasan diberikan kepada mitra yang mengelola syirkah. Mitra pengelola secara leluasa dapat menjalankan bisnis selama tidak bertentangan dengan tujuan dasar perjanjian syirkah, yaitu menghasilkan laba. Ibn Qudâmah menyebutkan beberapa perbuatan yang tidak boleh dilakukan oleh para mitra, antara lain misalnya, memerdekakan budak

${ }^{22}$ Chairuman Pasaribu dan Sahrawardi K. Lubis, Hukum Perjanjian dalam Islam (Jakarta: Sinar Grafika, 1996), h. 79.

${ }^{23}$ Q.S. al-Baqarah/2:282-283. Lihat juga M. Umer Chapra, Towards a Just Monetary System (London: the Islamic Foundation, 1985), h. 252.

${ }^{24} \mathrm{Al}$-Zuhaylî, al-Fiqh al-Islâmî, h. 794. Lihat juga Ibn Rusyd, Bidâyah al-Mujtahid wa Nihâyah al-Muqtashid, Juz II (Beirut: Dâr al-Jîl, 1989), h. 407.

${ }^{25} \mathrm{Al}$-Zuhaylî, Al-Fiqh al-Islâmî, h. 796.

${ }^{26}$ Nabil A. Saleh, Unlawful Gain and Legitimate Profit in Islamic Law: Riba, Gharar and Islamic Banking (Cambridge: Cambridge University Press, 1986), h. 92. 
(budak yang dimiliki salah satu mitra) dan meminjamkan uang milik kemitraan. Perbuatan yang demikian, meskipun pada dasarnya baik dan terpuji, merupakan tindakan yang tidak kondusif untuk pencapaian tujuan syirkah, yaitu menghasilkan laba. ${ }^{27}$

Mazhab Hanafi cenderung memberikan kebebasan lebih kepada mitra yang mengelola. Menurut mereka, mitra yang tidak terlibat dalam jual beli tidak dapat menerima bahkan memberikan suatu barang syirkah sebagai suatu ikatan janji atau jaminan. Jika ia melakukannya, maka tindakannya tidak sah, dan ia harus bertanggung jawab atasnya. Di lain pihak, mitra pengelola memiliki hak untuk memberikan barang syirkah sebagai jaminan dan untuk menerima perjanjian dari pihak lain. ${ }^{28}$ Kalangan mazhab Syafii dan Hanbali memandang bahwa masingmasing mitra dapat menjalankan hubungan kemitraan demi kepentingan syirkah laiknya praktik dagang. ${ }^{29}$ Menurut Ibn Qudamah, si mitra dapat melakukan apa saja dalam kepentingan bisnis berdasarkan kemitraan, karena inilah praktik yang lazim dalam perdagangan. ${ }^{30}$

Syirkah al-mufâwadhah adalah kerja sama dua orang atau lebih terhadap suatu objek dengan syarat masing-masing pihak memasukkan modal dengan jumlah yang sama dan dapat melakukan tindakan hukum yang sama atas nama orang yang berserikat. ${ }^{31}$ Semua pihak dalam syirkah ini memiliki kewajiban dan hak yang sama dalam perdagangan yang mereka sepakati, serta keuntungan yang diperoleh juga harus dibagi sama. Ulama mazhab Hanafi dan mazhab Zaidiyah (salah satu mazhab dalam Syi'ah) membolehkan bentuk syirkah ini dengan didasarkan pada sabda Rasulullah SAW.: "Jika kamu melaksanakan mufâwadhah, maka lakukanlah dengan carayang baik, karena akad seperti ini akan membawa berkah." Ulama mazhab Maliki juga memandang sah syirkah ini jika masing-masing pihak dapat bertindak hukum secara mutlak dan mandiri terhadap modal kerja tanpa minta izin dan musyawarah dengan pihak lain. Apabila salah satu pihak melakukan suatu transaksi, maka pihak lain terikat dengan transaksi yang telah dilakukannya itu. ${ }^{32}$

Pandangan kedua mazhab, Hanafi dan Zaidiyah, itu kontradiktif dengan pandangan ulama mazhab Syafi'i33 dan mazhab Hanbali. Kedua ulama yang terakhir ini menilai bahwa bentuk serikat mufâwadhah yang dipersepsikan oleh mazhab Hanafi dan Zaidiyah tidak dapat diterima karena sulit untuk menentukan prinsip kesamaan modal, kerja, dan keuntungan. ${ }^{34}$ Dalam serikat ini mengandung unsur yang kurang jelas dan unsur penipuan karena tidak mungkin tindakan seseorang akan dapat diterima pihak lain tanpa persetujuannya. Menurut mereka, hadis yang dijadikan dasar oleh mazhab Hanafi dan mazhab Zaidiyah adalah hadis

\footnotetext{
${ }^{27}$ Ibn Qudâmah, Mughnî al-Muhtâj, Jilid V, (t.t.p: t.p, t.t), h. 22.

${ }^{28}$ Jâzirî, Fiqh, Jilid III, h. 87.

${ }^{29}$ Ibid., h. 89.

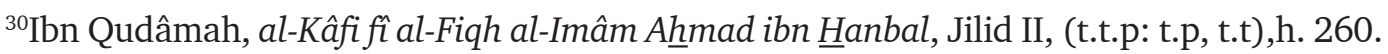

${ }^{31} I$ Ibid., h. 357-358.

${ }^{32} \mathrm{Al}-Z u h a y l i ̂, ~ a l-F i q h$ al-Islâmî, h. 799-800.

${ }^{33}$ Ibn Rusyd, Bidâyah al-Mujtahid, h. 410.

${ }^{34} \mathrm{Al}-Z u h$ haylî, al-Fiqh al-Islâmî, h. 799-801.
} 
dha'̂ff (lemah), bahkan tidak ada indikasi yang menunjukkan bahwa substansi hadis itu tertuju kepada serikat mufâwadhah.

Syirkah al-abdân adalah perserikatan yang dilakukan oleh dua orang untuk menerima suatu pekerjaan, dan keuntungan yang diperolehnya dibagi sesuai dengan kesepakatan bersama. ${ }^{35}$ Syirkah ini disebut juga syirkah a'mâl (syirkah kerja) atau syirkah shinâî (syirkah para tukang) atau syirkah taqabbul (syirkah penerimaan). ${ }^{36}$ Ulama Malikiyah dan Hanabilah memandang absah terhadap syirkah ini dengan alasan bahwa tujuan dari syirkah ini adalah untuk memperoleh keuntungan, tidak hanya pada harta, tetapi juga pada pekerjaan. Namun ulama Malikiyah mengajukan syarat bahwa pekerjaan yang dilakukan oleh orang yang berserikat ini harus sejenis, satu tempat dan hasil yang diperoleh harus dibagi menurut kuantitas kerja mereka masing-masing. Jadi, jika pekerjaannya tidak sejenis, dilaksanakan di tempat yang berbeda, dan tidak dibagi sesuai dengan porsi kerjanya, maka syirkah ini dipandang tidak sah. Ulama Hanabilah membolehkan syirkah ini sampai pada hal-hal yang mubah seperti pengumpulan kayu bakar dan rumput.

Sedangkan ulama mazhab Syafi'i berpandangan lain. Mereka mengatakan bahwa syirkah semacam ini tidak sah, karena pekerjaan yang dilakukan tidak dapat diukur secara pasti, sehingga ada kemungkinan terjadi penipuan. Begitu juga ulama Hanafiyah. Ia berpendapat bahwa perkongsian jenis ini dilarang, karena menurutnya, perkongsian dalam pekerjaan, seperti mencari kayu dan berburu, mengandung unsur perwakilan, padahal perwakilan tidak sah dalam perkara mubah sebab kepemilikannya dengan penguasaan. ${ }^{37}$

Syirkah al-wujûh adalah kerjasasama yang dilakukan oleh dua orang atau lebih yang tidak memiliki modal. Mereka mendapatkan barang secara kredit dan kemudian mereka jual secara kontan. Keuntungan yang diperoleh dibagi bersama. ${ }^{38}$ Dalam konteks kekinian, syirkah ini mirip dengan sistem makelar yang memang populer dan mentradisi di kalangan masyarakat. Ulama Hanafiyah dan Hanabilah membolehkan jenis syirkah ini, karena mengandung unsur adanya perwakilan dari seseorang kepada parternya dalam penjualan dan pembelian. Akan tetapi ulama Malikiyah, Syafi'iyah, dan Imamiyah berpendapat bahwa syirkah ini tidak sah dengan alasan bahwa syirkah ini tidak memiliki unsur modal dan pekerjaan yang harus ada dalam suatu perkongsian. ${ }^{39}$

Bentuk syirkah yang terakhir adalah syirkah al-mudhârabah, yaitu suatu perjanjian kerja sama antara dua pihak dimana salah satu pihak menyerahkan dan menyediakan seluruh modal untuk diperdagangkan oleh pihak lain sebagai pengelola, dan keuntungan yang diperoleh

${ }^{35}$ Alî Fikr, al-Mu 'âmalât al-Mâdiyah wa al-Adabîyah, Jilid I (Mesir: Mathba'ah Mushthafâ al-Bâb al-Halibî wa Awlâdih, 1938), h. 211. Lihat Zuhaylî, Al-Fikih, h. 803.

${ }^{36}$ Sâbiq, Fiqh al-Sunnah, h. 204.

${ }^{37}$ Zuhaylî, al-Fiqh, h. 803-804.

${ }^{38}$ Ibid., h. 801. Lihat Sâbiq, Fiqh al-Sunnah, h. 359.

${ }^{39}$ Ibid., h. 802. 
dibagi sesuai kesepakatan. ${ }^{40}$ Para ulama tidak ada perbedaan pendapat tentang kebolehan syirkah ini. Kerja sama semacam ini sudah terjadi sejak dahulu. Nabi Muhammad SAW. sendiri sebelum menjadi rasul melakukan kerja sama dengan Siti Khadijah dalam bentuk mudhârabah . Karena hal ini sesuai dengan tujuan syariat, yaitu menciptakan kemaslahatan dan menghindari kesulitan bagi manusia, maka Islam mengadopsinya. Pada era modern sistem mudhârabah semakin terasa urgensinya untuk menjaga keseimbangan kaya-miskin atau untuk menghidari kecemburuan sosial. ${ }^{41}$

Kedua, Rukun dan Syarat Musyârakah. Secara umum, telah menjadi konsesi para ahli fikih, bahwa rukun syirkah terdiri dari tiga unsur, yaitu: a) dua orang yang berakad, b) shighat akad, yakni îjâb dan qabûl, dan c) objek akad, yakni harta dan pekerjaan. ${ }^{42}$ Konsensus mayoritas ahli fikih itu bukanlah konsensus mutlak dan tanpa ada yang berbeda. Keberbedaan dalam fikih lazimnya menjadi suatu keniscayaan alamiah yang, "bisa jadi", muncul dari cara pandang yang berbeda. Sehingga dalam kaitan ini, bagi Hanafiyah, rukun syirkah hanya mencakup satu unsur, yaitu shighat (pernyataan), baik pernyataan penawaran (îjâb) ${ }^{43}$ maupun pernyataan menerima tawaran (qabûl) ${ }^{44}$, karena pernyataan îjâb dan qabûl ini merupakan elemen dasar

40`Alî Fikr, Al-Mu'âmalât, h. 179.

${ }^{41}$ Helmi Karim, Fikih Mu'amalah (Jakarta: RajaGrafindo Persada, 1997), h. 13.

${ }^{42}$ Alî Fikr, Al-Mu 'âmalât, h. 225.

${ }^{43}$ Dalam Hukum Perjanjian Syari'ah, Syamsul Anwar menjelaskan konsep îjâb secara detil. Ia mengatakan bahwa $\hat{\jmath} j a ̂ b$ adalah "suatu pernyataan kehendak yang pertama mucul dari sutau pihak untuk melahirkan sutau tindakan hukum, yang dengan pernyataan kehendak tersebut ia menawarkan pencapaian tindakan hukum yang dimaksud di mana bila penawaran itu diterima oleh pihak lain terjadilah akad". Sebagai contoh adalah pernyataan penjual, "Saya jual barang ini dengan harga sekian", atau sebaliknya, pernyataan pembeli, "Saya beli barang ini dengan harga sekian". Jadi, pernyataan penjual dalam kasus pertama dan pernyataan pembeli dalam kasus kedua adalah $\hat{j} j a ̂ b$ (penawaran) karena kedua pernyataan tersebut adalah pernyataan yang pertama muncul tanpa memperhatikan apakah pernyataan itu adalah dari pihak pertama ataupun dari pihak kedua. Jadi, menurut mazhab Hanafi ini, yang menjadi dasar untuk menentukan îjâb adalah melihat mana pernyataan yang terlebih dahulu muncul. Sedangkan mazhab Syâfiî̀ dan mazhab Hanbali mengajarkan bahwa îjâb selalu merupakan pernyataan yang lahir dari pihak pertama (dalam hal ini pihak yang memindahkan milik), meskipun pernyataan itu muncul kemudian. Maksud dan isi îjâb selain disyaratkan harus jelas, juga disyarakatkan harus tegas. Jelas, artinya, bahwa ungkapan—baik lisan, tulisan, isyarat muupun lainnya-yang digunakan untuk menyatakan îjâb dalam setiap akad menunjukkan secara jelas jenis akad yang dikehendaki, karena akad itu satu sama lain berbeda baik tujuannya maupun akibat hukum yang timbul. Karenanya, akad mana yang dimaksud dan akibat hukum apa yang hendak diciptakan haruslah jelas. Tegas, artinya, bahwa ungkapan seseorang yang menyampaikan ijab tidak disertai dengan hal-hal yang menunjukkan ketidaksungguhan untuk melahirkan sutau akad. Misalnya, pernyataan penjual atau pembeli yang disertai kata ("akan", pen.) yang menunjukkan "waktu akan datang". Kata "akan" menggambarkan "ketidaksungguhan" untuk melahirkan akad pada saat itu dan karenanya tidak terjadi akad dengan ijab seperti itu melainkan hanya pengumunan kehendak yang bersangkutan akan melakukan penjualan atau pembelian. Lihat penjelasan selengkapnya dalam Syamsul Anwar, Hukum Perjanjian Syari'ah: Studi tentang Teori Akad dalam Fikih Muamalat (Jakarta: RajaGrafindo Persada, 1997), h. 127-128.

${ }^{44} Q a b \hat{u} l$ adalah pernyataan kehendak yang menyetujui $\hat{\jmath} j a ̂ b$ dan yang dengannya tercipta suatu akad. Seperti halnya îjâb, qabûl juga disyaratkan kejelasan maksud, ketegasan isi, dan 
dalam perjanjian. Harta (modal) dan dua orang yang berakad, menurutnya, bukanlah unsur pokok kerja sama sebagaimana yang terdapat dalam jual beli. Bentuk pernyataan, dalam kerja sama, adalah seperti perkataan "Saya bekerja sama dalam hal ini", disebut dengan îjâb, dan kemudian dijawab (qabûl) oleh pihak lain dengan mengatakan "Saya terima dalam hal ini".

Sedangkan syarat sahnya syirkah, menurut ulama Hanafiyah, meliputi syarat umum dan syarat khusus. Syarat-syarat yang secara umum harus terpenuhi dalam syirkah adalah a) dapat dipandang sebagai perwakilan, artinya, jika salah satu pihak bertindak hukum terhadap objek perserikatan, dengan ijin pihak lain, maka dianggab sebagai wakil seluruh pihak yang berserikat, b) ada kejelasan dalam pembagian keuntungan; dan c) keuntungan itu diambil dari hasil laba harta perserikatan, bukan dari harta lain. ${ }^{45}$ Adapun syarat-syarat khusus dalam syirkah al-amwâl, baik berbentuk 'inân maupun berbentuk mufâwadhah, adalah a) modal harus ada dan jelas, tidak boleh barang utang atau harta yang tidak ada di tempat, baik ketika akad maupun ketika jual beli, dan b) modal harus bernilai dan berharga secara mutlak, seperti uang. Karena itu, tidak sah modal syirkah yang berwujud barang, baik barang yang bergerak maupun barang yang tetap. ${ }^{46}$

Syarat khusus syirkah al-mufâwadhah, menurut mazhab Hanafi dan Zaidiyah, yang membolehkan syirkah ini adalah a) setiap pihak harus ahli dalam perwalian dan jaminan, yakni keduanya harus merdeka, baligh dan berakal sehat, b) ada kesamaan modal dari segi ukuran, harga awal dan akhir, c) apa pun yang pantas menjadi modal dari salah seorang yang

didengar atau diketahui oleh pihak lain. Bila îjâb ditujukan kepada pihak tertentu, maka qabûl hanya sah dari pihak tersebut, dalam arti bilamana diberikan qabûl oleh pihak lain yang bukan pihak yang kepadanya $\hat{\jmath} j a ̂ b$ ditujukan, maka tidak tercipta akad. Isi yang terkandung dalam qabûl harus sesuai dengan îjâb dalam arti tidak menambahi, mengurangi, atau mungubah îjâb. Namun jika terjadi demikian, maka tidak tercipta akad dan qabûl tersebut dianggab sebagai îjâb baru yang memerlukan qabûl lagi. Ibid., h. 132.

${ }^{45} \mathrm{Al}$-Zuhaylî, al-Fiqh al-Islâmî, h. 804-805.

${ }^{46} \mathrm{Ibid}$., h. 806-808. Para ulama berbeda pandangan tentang modal yang diberikan masingmasing pihak, apakah harus disatukan atau tidak. Ulama mazhab Hanafi, Maliki dan Hanbali berpendirian bahwa modal tersebut tidak harus disatukan karena secara substantif syirkah terlaksana melalui transaski (akad) bukan modal, dan sumber transaksi, dalam konteks ini, adalah perbuatan (kerja). Selain itu, menurut mereka, akad syirkah mengandung makna perwakilan dalam bertindak hukum, dan dalam akad perwakilan modal masing-masing pihak diperbolehkan tidak disatukan. Karenanya, dalam akad syirkah tersebut juga diperbolehkan untuk tidak menyatukan modal mereka masing-masing. Namun ulama mazhab Maliki menyatakan bahwa pengertian "tidak menyatukan harta" bukan berarti "terpisah", tetapi harus ada suatu pernyataan hukum terhadap penyatuan modal itu. Misalnya melalui suatu pernyataan yang dituangkan dalam surat transaksi. Lihat Abdul Aziz Dahlan (ed.), Ensiklopedi Hukum Islam, Jilid V (Jakarta: Ichtiar Baru van Hoeve, 1996), h. 325. Ulama mazhab Syâfi'î bependapat bahwa dalam syirkah al-amwâl modal masing-masing pihak harus disatukan sebelum akad dilaksanakan, sehingga tidak bisa dibedakan modal kedua belah pihak, karena syirkah menurut mereka berarti percampuran dua harta. Menurut Ibn Rusyd, cara terbaik untuk menyelesaikan perbedaan tersebut adalah kedua harta (modal) itu "lebih baik" dan "lebih sempurna" disatukan, karena semua pihak mempunyai hak dan kewajiban yang sama terhadap harta itu, sehingga kehadiran unsur "keraguan" dan "kecurigaan" dari masing-masing pihak tidak terjadi. Lihat Ibid., h. 325. 
bersekutu dimasukkan dalam syirkah, d) ada kesamaan dalam pembagian keuntungan, e) ada kesamaan dalam berdagang, dan f) dalam transaksi (akad) harus menggunakan kata mufâwadhah atau pernyataan lain yang semakna dengan kata mufâwadhah. ${ }^{47}$ Dengan demikian, jika salah satu syarat tidak terpenuhi, maka syirkah ini akan berubah menjadi syirkah al'inân, karena syirkah al-'inân tidak menuntut seluruh persyaratan di atas. ${ }^{48}$

Syarat khusus syirkah al-abdân dibedakan antara yang berbentuk mufâwadhah dan yang berbentuk inân. Jika berbentukmufâwadhah, maka syirkahnya harus memenuhi persyaratan mufâwadhah, dan jika syirkahnya berbentuk 'inân, maka hanya disyaratkan ahli dalam perwakilan saja. Menurut ulama Hanafiyah setiap yang sah menjadi wakil, sah juga menjalankan syirkah. Namun demikian, jika pekerjaan membutuhkan alat dan alat itu dipakai salah satu pihak, hal itu tidak mempengaruhi syirkah. Tetapi, jika membutuhkan orang lain, maka pekerjaan itu akan menjadi tanggung jawab pihak yang menyuruh dan syirkah dipandang rusak. ${ }^{49}$

Demikian juga syarat-syarat khusus untuk syirkah al-wujûh. Jika syirkah ini berbentuk mufâwadhah, maka yang bersekutu itu harus ahli dalam memberikan jaminan, dan masingmasing memiliki setengah harga yang dibeli. Selain itu, keuntungan dibagi dua ketika akad harus menggunakan kata mufâwadhah. Jika syirkah berbentuk 'inân, maka tidak disyaratkan harus memenuhi persyaratan di atas, dan salah seorang boleh melebihi yang lain. Hanya saja keuntungan harus didasarkan pada kadar tanggungannya. Jika meminta lebih, akan batal. ${ }^{50}$

Menurut ulama mazhab Hanbali-ulama yang memandang mudhârabah tergolong sebagai salah satu bentuk syirkah-ada beberapa syarat yang harus dipenuhi, yaitu: a) modal berupa uang tunai yang berlaku, b) jumlah modal sudah diketahui besarnya sebelum akad, c) modal harus jelas ada, tidak berupa utang, dan d) modal diserahkan sepenuhnya kepada pengusaha (mudhârib). ${ }^{51}$ Syarat keempat inilah yang membedakan syirkah al-amwâl dengan mudhârabah. Dalam syirkah al-amwâl modal boleh dipegang oleh pemiliknya, sementara dalam syirkah al-mudhârabah, pekerjaan atau usaha tidak akan terwujud jika modal tetap di tangan pemiliknya, karena dalam mudhârabah salah satu pihak sebagai penyandang dana dan pihak lainnya sebagai pelaksana. Syirkah al-amwâl terjadi karena ada kerja sama dalam usaha diantara kedua pihak. Jika salah satu disyaratkan bebas dari pekerjaan atau usaha, maka syarat ini bertentangan dengan tujuan akad, begitu juga jika dalam mudhârabah disyaratkan adanya usaha dari pemilik harta, maka syirkah al-mudhârabah menjadi fasid. ${ }^{52}$

Ketiga, Sistem Bagi Hasil dalam Musyârakah. Pembahasan dalam bagian ini tidak menyentuh persoalan syirkah secara keseluruhan. Syirkah jenis pertama, yaitu syirkah

${ }^{47} \mathrm{Al}$-Zuhaylî, al-Fiqh al-Islâmî, h. 811-812.

${ }^{48}$ Ketentuan tentang syirkah al-'inân juga dapat dilihat dalam Ibn Rusyd, Bidâyah alMujtahid, h. 407.

${ }^{49} \mathrm{Al}-Z u$ haylî, al-Fiqh al-Islâmî, h. 813-814.

${ }^{50}$ Ibid., h. 814.

${ }^{51}$ Ibid., h. 843-846.

${ }^{52}$ Ibid., h. 847. 
al-amlâk, tidak dibahas, karena syirkah tipe ini tidak dianggap sebagai suatu kemitraan dalam pengertian sesungguhnya. Syirkah al-amlâk yang secara esensial merupakan suatu kepemilikan bersama atas suatu kekayaan muncul bukan atas dasar kesepakatan untuk berbagi "untung" dan "rugi", tetapi keberadaannya timbul secara otomatis, dan karenanya, kajian sistem bagi hasil tidak mewujud dalam syirkah ini. ${ }^{53}$ Dengan demikian, maka yang dimaksud syirkah dalam kajian ini adalah syirkah al-'uqûd. Syirkah al-'uqûd ada yang sahih dan ada yang fasid. Syirkah yang fasid adalah syirkah yang tidak terpenuhi salah satu syaratnya. Jika fasid, maka menurut ulama Hanafiyah, Syafi'iyah, dan Hanabilah, keuntungannya dibagi sesuai dengan modal awal masing-masing dan jika syirkah itu sahih (terpenuhi syarat-syarat syirkah), maka pembagian hasilnya disesuaikan dengan jenis syirkahnya. Terlepas dari perdebatan ulama, maka dalam bagian ini akan dikaji tentang konsep bagi hasil dari lima bentuk syirkah yang tergolong dalam kategori syirkah al-'uqûd, yaitu syirkah al-'inân, syirkah al-abdân, syirkah al-wujûh, syirkah al-mufâwadhah, dan syirkah al-mudhârabah.

Bagi hasil dalam syirkah al-inân tidak ditentukan dengan jumlah yang pasti, melainkan dengan nisbah (perbandingan) persentase tertentu, dan secara jelas, menurut mazhab Hanafi dan Hanbali, harus tertuang dalam kontrak. Menentukan suatu jumlah tetap bagi seorang mitra tidak diperbolehkan karena total laba yang akan diperoleh barangkali tidak akan melebihi jumlah yang telah ditetapkan, dan dalam kasus seperti itu, mitra lainnya bisa jadi tidak memperoleh bagian dari laba tersebut. ${ }^{54}$ Bagi kalangan mazhab Syafi'i, tidak perlu menetapkan bagian laba dalam kontrak, sebab mereka tidak memperbolehkan adanya perbedaan antara rasio saham dalam modal dengan rasio laba. Menurut ahli fikih bermazhab Syafi'i, Nawawi, "proporsi laba dan rugi harus sama dengan proporsi modal yang diberikan, baik tenaga yang disediakan oleh para mitra setara atau pun tidak". ${ }^{55}$ Selain kalangan mazhab Syafii, terdapat fleksibilitas yang berarti dalam menetapkan rasio. Pandangan yang membolehkan perbedaan rasio pembagian laba dengan rasio kontribusi dalam syirkah ini berasal dari mazhab Hanafi dan Hanbali. Para mitra dapat berbagi laba secara setara ataupun tidak. Seorang mitra yang menyumbangkan sepertiga dari modal syirkah, misalnya, dapat memperoleh separoh atau lebih dari laba. Menurut ahli fikih mazhab Hanafi, al-Kâsânî, "dalam 'inân, laba tidak harus dibagi setara antarmitra". Sebab itu, diperbolehkan untuk membagi laba secara setara ataupun tidak. Prinsipnya adalah bahwa si mitra berhak mendapat laba baik karena pemberian modal berupa uang atau tenaga kerja, atau berupa tanggung jawab. ${ }^{56}$

Bagi kalangan mazhab fikih Sunni, tidak muncul fleksibilitas dalam syirkah tentang pembagian rugi vis a vis rasio kontribusi modal, seperti yang dicerminkan dalam ungkapan

${ }^{53}$ M. Umer Chapra, Towards a Just Monetary System (London: The Islamic Foundation, 1985), h. 106.

${ }^{54}$ Ibn Qudâmah, Mughnî, Jilid V, h. 38. Lihat juga Imâm 'Alâ' al-Dîn Abî Bakr ibn Mas` ûd al-Kâsânî, Badâ'i' al-Shanâ 'i' fí Tartîb al-Syarâ 'i, Jilid VI (Beirut: Dâr al-Fikr, 1996), h. 59.

${ }^{55}$ Nawawî, Minhâj, Jilid II, h. 215.

${ }^{56}$ Kasânî, Badâ'i' al-Shanâ'i', Jilid VI, h. 62. 
hukum, "pembagian rugi harus persis sama dengan rasio kontribusi modal. ${ }^{57}$ Menurut al-Jazîrî, "jika salah satu mitra menentukan bahwa mitra yang lain harus menanggung risiko melebihi rasio kontribusi modal, maka kontrak ini batal dan tidak berlaku. ${ }^{58}$ Ini sejalan dengan prinsip yang dibangun oleh khalifah keempat, 'Ali ibn Abî Thâlib, yaitu "laba harus dibagi sebagaimana yang disepakati dalam kontrak, sementara kerugian harus dibagi menurut kontribusi modal."59

Dalam syirkah al-mufâwadhah, sebagaimana syarat yang dikemukakan di atas, harus ada kesamaan dalam modal, wewenang, pembagian keuntungan, dan jika terjadi kerugian, kedua belah pihak menanggung risiko kerugian yang timbul dari usaha mereka bersama. Karena modal yang diinvestasikan sama, maka pembagian keuntungan pun harus dibagi kepada kedua belah pihak secara bersama-sama sesuai dengan proporsi modal masingmasing. Sedangkan bagi laba dalam syirkah al-abdân bergantung pada tanggungan bukan pada pekerjaan. Apabila salah seorang pekerja berhalangan tidak dapat melakukan pekerjaan, keuntungan tetap dibagi dua, sesuai dengan kesepakatan. Pernyataan ini berimplikasi selain pada perbedaan pekerjaan yang dilakukan masing-masing anggota syirkah, juga pada keuntungan yang diperoleh. Risikonya adalah bahwa masing-masing pihak bertanggung jawab terhadap pekerjaan anggota lainnya. Jika terjadi hal-hal yang berkaitan dengan kerugian pihak yang memberi pekerjaan, hal itu menjadi tanggung jawab seluruh anggota syirkah. Masing-masing dapat dituntut membayar ganti rugi sesuai dengan tingkat perbandingan upah masing-masing, tidak dibebankan pada anggota yang mengakibatkan timbulnya kerugian tersebut.

Sistem bagi hasil dalam syirkah al-wujûh dihitung atas dasar perkiraan bagian mereka dalam kepemilikan, tidak boleh lebih dari itu, sebab syirkah ini didasarkan pada kadar tanggung jawab terhadap harta maupun pekerjaan. Dengan demikian, keuntungan pun harus diukur berdasarkan tanggung jawab, tidak boleh dihitung melebihi kadar tanggungan masingmasing. Bila terjadi kerugian, maka seluruh pihak memikul risiko sesuai dengan kadar tanggung jawabnya masing-masing. Sedangkan keuntungan usaha dalam syirkah al-mudhârabah dibagi menurut kesepakatan dalam kontrak, dan sebaliknya, jika mengalami kegagalan usaha, maka kerugian ditanggung oleh pemilik modal selama kerugian itu bukan akibat kelalaian pihak pengelola. Kedua belah pihak, secara substansial, akan bersama-sama menanggung risiko, dalam arti, di satu sisi pihak pemilik modal menanggung kerugian modalnya, dan di sisi lain pengelola akan mengalami kerugian atas tenaga atau biaya tenaga kerja yang telah dikeluarkan. Jika kerugian itu terjadi karena kecurangan atau kelalaian pihak pengelola, maka pihak pengelola harus bertanggung jawab atas kerugian tersebut.

${ }^{57}$ Ibn Qudâmah, Mughnî, Jilid V, h. 37

${ }^{58}$ Jâzirî, Fiqh, Jilid III, h. 77.

${ }^{59}$ Syawkânî, Nayl al-Awthâr, Jilid V, h. 266. 


\title{
Musyârakah dalam Praktik Perbankan
}

Term musyârakah, secara operasional, telah melekat dalam institusi keuangan syariah. Kelekatan musyârakah dalam perbankan syariah mencerminkan suatu kemitraan berpola kontrak PLS. ${ }^{60}$ Akseptabilitas terhadap pola ini membangun pemahaman bahwa kerja

\begin{abstract}
${ }^{60}$ Istilah "bagi hasil," yang populer dalam memaknai profit and loss-sharing (PLS) dan digunakan untuk menggambarkan operasional bank syari'ah, memang tidak seluruhnya salah dan tidak juga semuanya benar. Bank syari'ah memiliki ragam produk yang tidak hanya menggunakan pola bagi hasil tetapi juga memiliki produk yang bukan berdasarkan bagi hasil. Salah satu produk pembiayaan dengan pola bagi hasil, dalam pengertian umum, adalah musyârakah. Namun demikian, istilah "bagi hasil" yang secara umum merupakan representasi dari istilah revenue sharing memiliki makna yang berbeda dengan "bagi laba rugi". Walaupun sebenarnya bisa juga ada anggapan bahwa dalam istilah bagi hasil sudah termasuk pengertian bagi laba rugi. Jika istilah bagi hasil berarti yang dibagi antara pemodal dan pengusaha adalah berdasarkan hasil, maka dalam bagi laba rugi yang dibagi bukan hanya laba tetapi juga rugi. Pengertian hasil dalam terminologi akuntansi biasanya terbatas pada penerimaan kotor belum dikurangi biaya-biaya untuk mendapatkannya, sedangkan laba merupakan hasil pengurangan biaya dari penghasilan. Dalam konteks inilah secara sederhana para akuntan membangun formula untuk menghitung laba rugi. Formula tersebut adalah "hasil" dikurangi "biaya" sama dengan "laba". Misalnya, jika hasilnya senilai Rp. 100.000 dikurangi biaya sebesar Rp. 60.000,-, maka laba yang diperoleh sebesar Rp. 40.000,- Pembagian antara pemodal dan pengusaha mislanya bisa dilakukan dengan nisbah 3:7 dan nisbah ini bisa didasarkan pada tatacara bagi hasil atau bagi laba rugi. Jika dimisalkan nisbahnya sama, maka pembagian antara pemodal dan pengusaha tergambar dalam logika pembagian berikut. Jika dalam konteks bagi hasil mencapai nilai Rp. 100.000,-, maka pemodal akan memperolah bagian Rp. 30.000,- dan pengusaha memperoleh Rp. 70.000,-. Berbeda dengan logika bagi laba rugi. Dalam logika jenis terakhir tergambar bahwa jika bagi laba rugi mencapai sebesar Rp. 40.000,-, maka Rp. 12.000,-- adalah bagian pemodal dan Rp. 28.000,- menjadi bagian pengusaha. Dengan demikian, gambaran di atas menunjukkan difergensi pembagian sebagai konsekuesni logis dari perbedaan cara pandang dalam memaknai istilah "bagi hasil" dan "laba rugi". Dalam prinsip bagi hasil biasanya didasarkan pada hasil saja, sehingga setiap ada hasil, pemodal mendapat bagian sebesar yang disepakati, dan jika pengusaha mengalami kerugian, maka pengusaha yang akan menanggungnya. Logika nisbah yang demikian tentu tidak sejalan dengan sistem bagi laba rugi yang dianggap lebih sesuai dengan syari'ah karena dipandang lebih adil. Keadilan sebagai elemen penting dari maqâsid, sulit untuk memahami sebuah masyarakat Muslim ideal tanpa adanya keadilan di dalamnya. Islam benar-benar tegas dalam tujuannya untuk membasmi semua jejak kezaliman dari masyarakat manusia. Kezaliman adalah sebuah istilah menyeluruh yang mencakup semua bentuk ketidakadilan, eksploitasi, penindasan dan kemungkaran, dimana seseorang mencabut hak-hak orang lain atau tidak memenuhi kewajibannya kepada mereka. (M. Umer Chapra, 1999: 229). Penegakan keadilan dan pembasmian semua bentuk ketidakadilan telah ditekankan oleh al-Qur'an sebagai misi utama dari semua nabi yang diutus Tuhan (Q.S. al-Hadîd/57:25). Tidak kurang dari seratus ungkapan yang berbeda-beda dalam al-Qur'an yang memuat gagasan tentang keadilan, baik langsung dengan menggunakan kata-kata ' $a d l$, qisth, mîzân atau dalam berbagai ungkapan tidak langsung lainnya. Di samping itu, ada lebih dari duaratus peringatan dalam al-Qur'an yang menentang ketidakadilan yang diungkapkan dengan menggunakan kata-kata semisal zulm, itsm, dhalâl dan lain-lain. Bahkan al-Qur'an menempatkan keadilan lebih "dekat kepada takwa" (Q.S. al-Mâidah/5:8) berkaitan dengan kepentingannya di dalam kepercayaan Islam. Secara alami ketakwaan adalah yang terpenting karena menjadi batu loncatan bagi semua perbuatan baik, termasuk keadilan. Nabi Muhammad sangat tegas sikapnya dalam hal ini. Beliau menyamakan ketiadaan keadilan dengan kegelapan mutlak dan memperingatkan, "Waspadalah terhadap kezaliman karena kezaliman itu akan mengarah pada kegelapan mutlak di Hari Pembalasan". Tidak mengherankan, Ibn Taimiyah merasa terdorong untuk mengatakan, "Tuhan menegakkan
\end{abstract}


sama antara bank dan mitra dalam suatu proyek akan menyentuh salah satu di antara dua realitas yang berbeda, realitas "untung" atau realitas "rugi". Berbagi dalam "untung" dan "rugi" menjadi suatu keniscayaan dalam kemitraan musyârakah. Namun demikian, pembagiannya pun tetap harus patuh dan tunduk pada aturan main dan persyaratan musyârakah yang secara ijtihadi telah dibangun oleh ulama fikih. Dalam perbankan syariah, musyârakah dapat dipahami sebagai suatu mekanisme yang menyatukan kerja dan modal, selain untuk produksi barang dan jasa, juga untuk kegiatan lain yang bertujuan menghasilkan keuntungan. Pemahaman ini kemudian berimplikasi pada pemaknaan musyârakah dalam pengertian luas. Musyârakah, dalam konteks ini, dapat digunakan untuk tujuan dagang murni yang lazimnya bersifat jangka pendek, atau keikutsertaannya dalam investasi proyek jangka menengah hingga jangka panjang. Dengan demikian, berbagai jenis musyârakah yang digunakan dalam bank syariah mencakup musyârakah komersial (dagang), musyârakah berkurang, dan musyârakah permanen. ${ }^{61}$

Dalam musyârakah dagang, suatu perjanjian biasanya digunakan untuk tujuan khusus, seperti pembelian dan penjualan komoditas. Pihak bank dan mitranya sama-sama memberikan kontribusi modal untuk pembiayaan musyârakah, dengan dasar pembagian, bahwa pihak mitra memiliki tanggung jawab dalam pengendalian usaha, baik pembelian, penjualan, pemasaran, maupun akuntansi yang terkait dengan transaksi, sementara pihak bank bertanggung jawab mendanai bagian transaksi, menyediakan pelayanan perbankan (yang diperlukan) dan memantau kemajuan musyârakah melalui nota berkala yang dilaporkan oleh pihak mitra.

Kontrak musyârakah dagang, bagi bank syariah, tidak hanya dapat mempercepat pencairan dana dan memacu sirkulasi modal lebih besar, sehingga keuntungan pun bisa lebih banyak, tetapi juga akan mampu memperluas zona usaha dan mereduksi berbagai risiko dalam pelaksanaan investasinya. Dalam kaitan ini, para ulama memang tidak menetapkan rasio modal secara baku dan pasti. Bukan berarti ini merupakan harga mati dan menutup rapat tawaran tentang kejelasan rasio modal hadir dalam kontrak musyârakah tipe ini. Husain Kamil dan Gharib Nasher, selaku praktisi perbankan syariah, mengatakan bahwa rasio modal, secara umum, tergantung pada karakteristik personal mitra bank, jumlah penyertaan modal, dan keamanan maupun risiko yang mungkin terjadi dalam kemitraan mereka. Dalam Faisal Islamic Bank of Sudan, misalnya, penyertaan modal dari pihak mitra bisa mencapai

negeri yang adil meskipun kafir, tetapi tidak menegakkan negeri yang tidak adil sekalipun beriman", dan bahwa "Dunia dapat selamat dengan keadilan dan kekafiran, tetapi tidak dengan ketidakadilan dan Islam". Ketidakadilan dan Islam adalah berbeda satu dari yang lain dan tidak dapat hidup berdampingan tanpa ada salah satu yang tumbang atau lemah. Komitmen yang besar pada keadilan menuntut agar sumber daya yang tersedia bagi umat digunakan untuk mewujudkan maqâshid syarî ah, empat di antaranya cukup penting dalam kerangka pembicaraan di sini, yaitu a) pemenuhan kebutuhan, b) penghasilan yang diperoleh dari sumber yang baik, c) distribusi pendapatan dan kekayaan yang adil, dan d) pertumbuhan dan stabilitas.

${ }^{61}$ Abdullah Saeed, Islamic Banking and Interest (Leiden: E.J. Brill, 1996), h. 62. 
40\%, terutama dalam transaksi yang terkait dengan perdagangan. ${ }^{62}$ Kebijakan bank menetapkan rasio modal itu ternyata berjalan lancar dan tidak menuai kritik dari para ahli fikih. Dengan demikian, kealpaan kritik mengindikasikan kebolehan dan urgensitas "rasio modal" masuk dalam wilayah musyârakah dagang guna memberikan kepastian dalam kontrak kemitraan. ${ }^{63}$

Adapun musyârakah model kedua, yakni "musyârakah berkurang," didefinisikan sebagai suatu kemitraan yang memungkinkan pihak mitra menambah kepemilikan usaha secara bertahap sesuai dengan syarat-syarat yang telah ditetapkan dalam kontrak. Para mitra (nasabah) jenis syirkah ini adalah para pihak yang diklaim tidak tertarik dengan kemitraan permanen, bahkan mereka cenderung untuk segera memperoleh kemilikan penuh dalam proyeknya. Dalam musyârakah ini, bank memberikan pembiayaan dengan prinsip penyertaan yang memungkinkan dua kondisi yang berbeda, yaitu; kondisi pertama, pihak bank secara bertahap akan melepaskan penyertaannya, dan kondisi kedua, pihak nasabah (pengusaha) akan mengambil alih porsi penyertaan bank, baik dengan dananya sendiri sebagai penambahan setoran modal, atau mengundang pemegang saham baru. ${ }^{64}$ Keberbedaan dua keadaan itu secara nyata menggambarkan bahwa porsi modal bank semakin lama semakin berkurang, dan pada akhirnya bank akan menyentuh titik nol porsi modal (zero equity), karena itu, pihak bank tidak lagi terlibat sebagai mitra. Ketika porsi modal bank menurun sampai titik nol, berarti kepemilikian modal sepenuhnya telah beralih kepada pihak nasabah. ${ }^{65}$

${ }^{62}$ Ibid., h. 63.

${ }^{63}$ Dalam musyârakah dagang, waktu penyelesaian musyârakah secara myata juga harus ditentukan. Tadamon Islamic Bank, misalnya, menyatakan bahwa perkiraan masa berlangsungnya kontrak biasanya ditetapkan untuk mengakhiri musyârakah. Jika nasabah tidak mampu mengelola usaha sampai masa tertentu, maka pihak bank disamping akan mengambil alih dan mengganti pengelolaan musyârakah tersebut sebagai konsekuensi dari bagian kemitraan, ia juga akan membatalkan kontrak tersebut. Ibid.

${ }^{64} Z$ Zainul Arifin, Dasar-dasar Manajemen Bank Syari'ah (Jakarta: AlvaBet, 2003), h. 208.

${ }^{65}$ Lewis, Perbankan Syari'ah, h. 81. Reduksi keterlibatan pihak bank dapat dilakukan melalui salah satu cara berikut. a) bank dan nasabah sepakat atas kontribusi modal masing-masing dan menentukan syarat-syarat kontraknya. Ketika kontrak musyârakah berakhir, maka kontrak terpisah lainnya ditandatangani, untuk kemudian memungkinkan pihak bank menjual sahamnya kepada pihak lain. Kontrak yang terakhir ini akan menentukan dan memastikan cara penjualan saham dan masa berlakunya. Dalam konteks inilah pihak pembeli harus membayar saham bank secara berangsur-angsur, b) pihak bank dan nasabah menetapkan bahwa investasi mereka dalam musyârakah akan berbentuk saham-saham yang mewakili seluruh nilai musyârakah. Setiap pihak akan menerima keuntungan berdasarkan jumlah saham yang dimiliki. Nasabah bebas membeli saham bank setiap tahunnya yang dengan itu jumlah saham (bagian) bank akan berkurang secara bertahap sampai pihak nasabah dapat membeli semua saham bank. Pada akhirnya nasabah akan menjadi pemilik tunggal kongsi musyârakah, atau opsi yang terakhir, c) pihak bank sepakat dengan nasabah untuk pembiayaan suatu proyek, baik dengan dana sepenuhnya atau sebagiannya dari bank, dengan syarat bahwa pihak bank akan menerima bagian labanya secara berkala dan menahan seluruh atau sebagian laba pihak nasabah untuk menutupi pembiayaan yang telah disalurkan oleh pihak bank. Ketiga pola opsional di atas telah dilaksanakan oleh bank-bank Islam, bahkan kehadiran ketiganya disambut baik oleh Konferensi Perbankan Islam yang diselenggarakan di Dubai pada tahun 1979. Lihat Saeed, Islamic Banking, h. 64. Apresiasi positif yang demikian adalah dengan cara bahwa konferensi mengamini dan telah memberi "ijin" operasional terhadap ketiga cara itu. Namun 
Sedangkan bentuk musyârakah yang terakhir adalah musyârakah permanen. Kontrak musyârakah permanen ini merupakan suatu kontrak dimana pihak bank membiayai sekian porsi modal untuk suatu proyek tertentu sebagai pemegang saham, dan bank berpartisipasi dalam manajemen dan pengawasan proyek bersama dengan mitranya, dengan syarat bahwa bank akan berbagi keuntungan atau kerugian proyek sebagaimana yang disepakati dalam kontrak. Istilah "permanen" tidak berarti "selamanya", sebab jenis kemitraan ini hanya berjalan sampai selesainya proyek atau sampai berakhirnya waktu yang ditetapkan dalam kontrak.

Pertama, Aturan main kemitraan. Aturan main, dalam bisnis apapun, merupakan hal yang sangat urgen, karena ia ikut mengarahkan dan sekaligus menjamin kelangsungan suatu bisnis secara teratur dan benar. Dalam konteks musyârakah (kemitraan), aturan main yang tetuang dalam suatu kontrak menjadi penting, karena akan memastikan, membatasi dan mengarahkan gerak para mitra dalam menjalankan musyârakah agar tetap sesuai dengan nilai-nilai syariah (Islam).

Ketentuan musyârakah yang semestinya dikonstruk dalam perbankan syariah, seperti yang difatwakan MUI, mencakup empat hal pokok; 1) pernyataan ijab dan kabul harus dinyatakan oleh para pihak untuk menunjukkan kehendak dalam mengadakan kontrak, dengan tetap mempertimbangkan tiga elemen, yaitu; a) penawaran dan penerimaan harus secara eksplisit menunjukkan tujuan kontrak, b) penerimaan dan penawaran dilakukan pada saat kontrak, dan c) akad harus disampaikan secara tertulis baik melalui korespondensi maupun melalui sarana komunikasi modern, ${ }^{66} 2$ ) para pihak harus cakap hukum, ${ }^{67}$ dengan memperhatikan hal-hal, antara lain; a) kompeten dalam memberikan atau diberikan kekuasaan perwakilan, b) setiap mitra harus menyediakan dana dan pekerjaan, dan setiap mitra melaksanakan kerja sebagai wakil, c) setiap mitra memiliki hak untuk mengatur aset musyârakah dalam proses bisnis normal, d) setiap mitra memberi wewenang kepada mitra yang lain untuk mengelola aset dan masing-masing dianggap telah diberi wewenang untuk melakukan aktifitas musyârakah dengan memperhatikan kepentingan mitranya, tanpa melakukan kelalaian dan kesalahan yang disengaja, dan e) seorang mitra tidak diijinkan untuk mencairkan atau menginvestasikan

demikian, pilihan pola itu bukan tanpa kritik, tetapi justru menuai kritik tajam dari sebagian pakar. Memang tidak semua kehadirannya dikritik dan ditolak. Kritik dan penolakan pedas tertuju pada cara yang terakhir yang memiliki kemiripan dengan riba, karena bank terlibat sebagai salah satu pihak dengan memberikan syarat bahwa pihak bank akan memperoleh kembali semua biaya yang disalurkannya, dan setelah itu, bank juga menerima prosentasi keuntungan dari proyek.

${ }^{66}$ Dewan Syariah Nasional Majelis Ulama Indonesia, "Fatwa Dewan Syariah Nasional No. 08/DSN-MUI/IV/2000 tentang Pembiayaan Musyarakah," dalam Himpunan Fatwa Dewan Syari'ah Nasional (Jakarta: DSN-MUI dan BI, 2003), h. 53.

${ }^{67}$ Kecakapan hukum (al-ahlîyah) berarti "kelayakan". Pemaknaan ini mengandung pemahaman bahwa kecakapan hukum merupakan kelayakan seseorang untuk menerima hukum dan bertindak hukum, atau sebagai kelayakan seseorang untuk menerima hak dan kewajiban dan untuk diakui tindakan-tindakannya secara hukum syari'ah. Penjelasan secara detail dapat dilihat dalam Anwar, Hukum Perjanjian, h. 109-112. 
dana untuk kepentingannya sendiri, ${ }^{68} 3$ ) objek akad meliputi modal, kerja, keuntungan dan kerugian. ${ }^{69}$ Ketentuan yang terakhir, 4 ), adalah bahwa biaya operasional ${ }^{70}$ dibebankan pada modal bersama. Namun jika salah satu pihak tidak menunaikan kewajibannya atau jika terjadi perselisihan di antara para pihak, maka penyelesaiannya dilakukan melalui badan yang berwenang setelah tidak tercapai kesepakatan melalui musyawarah. ${ }^{71}$

Selain ketentuan di atas, berbagai perbankan syariah juga mensyaratkan aneka aturan lain yang tidak bertentangan dan tetap paralel dengan normativitas dan nilai-subtantif fikih. Kesesuaian dan paralelitas itu dibangun setidaknya untuk mewujudkan dua kesalehan, "kesalehan" bank dan "kesalehan" nasabah sebagai mitra. Mitra harus menyimpan barangbarang musyârakah (dagang), di bawah pengawasan bersama dan tidak boleh ada satu barang pun dijual sebelum harga jual dimasukkan ke dalam catatan musyârakah. Pihak mitra mengelola musyârakah dan menjual barang-barang pada waktu yang kondusif. Barangbarang harus dijual secara tunai dan dengan harga yang telah disepakati oleh pihak bank dan mitra, yang dalam banyak kasus, bahkan dinyatakan dalam kontrak. Mitra tidak boleh menjual barang dengan harga lebih rendah daripada yang disepakati, kecuali ada ijin tertulis dari bank. Jika mitra menjual barang dengan harga lebih rendah dan tanpa ijin bank, maka ia harus mengganti uang selisihnya untuk pihak bank. Pihak mitra harus melakukan pembukuan yang terpisah dan layak bagi musyârakah serta didukung oleh dokumen yang transparan dan relevan serta faktur yang sah secara hukum. Bank memiliki hak untuk melakukan inventarisasi barang kapan pun tanpa boleh ada keberatan dari nasabah. ${ }^{72}$ Bank memiliki hak untuk memeriksa, secara periodik maupun insidentil, terhadap pos-pos dalam laporan

${ }^{68}$ Majelis Ulama Indonesia, "Fatwa," h. 53-54.

${ }^{69}$ Modal yang diberikan harus berupa uang tunai, emas, perak, atau yang nilainya sama. Modal dapat terdiri dari aset perdagangan, seperti barang-barang, properti dan sebagainya. Jika modal berbentuk aset, harus terlebih dahulu dinilai dengan tunai dan disepakati oleh para mitra. Para pihak tidak boleh meminjam, meminjamkan, menyumbangkan atau menghadiahkan modal musyârakah kepada pihak lain. Dalam hal perkerjaan, partisipasi para mitra merupakan dasar pelaksanaan musyârakah, akan tetapi kesamaan porsi kerja bukan merupakan syarat. Seorang mitra boleh melaksanakan kerja lebih banyak dari yang lainnya, dan dalam hal ini ia boleh menuntut bagian keuntungan tambahan darinya. Setiap mitra melaksanakan kerja dalam musyârakah atas nama pribadi dan wakil dari mitranya. Kedudukan masing-masing dalam organisasi kerja harus dijelaskan dalam kontrak. Keuntungan harus dikuantifikasi dengan jelas untuk menghindarkan perbedaan dan sengketa pada waktu alokasi keuntungan atau ketika penghentian musyârakah. Setiap keuntungan mitra harus dibagikan secara proporsional atas dasar seluruh keuntungan dan tidak ada jumlah yang ditentukan di awal yang ditetapkan bagi seorang mitra. Seorang boleh mengusulkan bahwa jika keuntungan melebihi jumlah tertentu, kelebihan atau prosentasi itu diberikan kepadanya. Sistem pembagian keuntungan harus tertuang dengan jelas dalam akad. Jika suatu usaha mengalami kerugian, maka kerugian harus dibagi diantara para mitra secara proporsional menurut saham masing-masing dalam modal. Ibid., h. 54-56.

${ }^{70}$ Untuk mencegah adanya biaya yang tidak dapat dikontrol, maka pihak bank dapat mensyaratkan revenue sharing atau menentukan minimal profit margin yang dikehendaki. Lihat Buku Pedoman Pembiayaan Kecil Syariah pada BNI Syari'ah, "Pembiayaan Musyarakah," 2007, h. 1.

${ }^{71}$ Majelis Ulama Indonesia, "Fatwa," h. 56.

${ }^{72}$ Buku Pedoman, "Pembiayaan," h. 2. 
keuangan, sehingga akan dengan mudah dapat diketahui cash flow nasabah. ${ }^{73}$ Pihak mitra harus memberikan laporan berkala tentang kondisi barang milik kemitraan, baik jumlah barang yang terjual maupun sisa barang yang tersimpan di gudang. ${ }^{74}$ Bank memiliki hak untuk meminta laporan semacam ini kapanpun bank memandangnya perlu. Pihak mitra harus selalu menjaga keamanan barang dari segala risiko selama jangka waktu musyârakah. Ia tidak boleh mencampur aduk barang syirkah dengan barang miliknya sendiri ${ }^{75}$ tanpa ijin bank sebagaimana ia juga tidak boleh memberikan, meminjamkan, atau menggunakannya untuk meminjam uang sebagai jaminan. ${ }^{76}$ Ia pun tidak boleh memberikan salah satu aset pribadinya sebagai jaminan bagi pihak ketiga tanpa izin tertulis dari pihak bank. ${ }^{77}$

"Jaminan" dalam bank konvensional merupakan "suatu keharusan". Ini berbeda dengan bank yang berbasis syariah. "Jaminan" sebenarnya tidak dibenarkan hadir dalam perbankan syariah, karena, menurut fuqaha, mitra adalah orang yang dipercaya, dan atas dasar "kepercayaan" ini, maka mitra yang satu tidak dapat menuntut jaminan dari pihak lain. Ini berarti bahwa "kepercayaan" hakikatnya merupakan suatu "jaminan". Walaupun pada prinsipnya jaminanbukan dalam arti "kepercayaan"-tidak dibenarkan, namun ulama Indonesa melalui fatwanya memberikan kelonggaran bagi bank-bank Islam untuk meminta jaminan kepada pihak mitra. ${ }^{78}$ Atas dasar fatwa ini, maka bank-bank syariah mensyaratkan mitranya untuk memberikan jaminan guna mereduksi risiko bank dalam kegiatan pembiayaan musyârakah. ${ }^{79}$ Risiko yang relatif sering terjadi, menurut Antonio, mencakup tiga hal, yaitu; a) side streaming, yakni nasabah menggunakan dana musyârakah bukan seperti yang disebut dalam kontrak, b) lalai dan kesalahan yang disengaja, dan c) penyembunyian keuntungan oleh nasabah, jika nasabahnya tidak jujur. ${ }^{80}$ Dengan demikian, jaminan menjadi suatu keharusan sebagai alat kendali untuk memproteksi dan, paling tidak, dapat memperkecil risiko yang sengaja diciptakan oleh nasabah. ${ }^{81}$

${ }^{73}$ Ibid., h. 1.

${ }^{74}$ Ibid., h. 2.

${ }^{75}$ Heri Sudarsono, Bank dan Lembaga Keuangan Syari'ah: Deskripsi dan Ilustrasi (Yogyakarta: Ekonisia, 2004), h. 68.

${ }^{76}$ Majelis Ulama Indonesia, "Fatwa," h. 55.

${ }^{77}$ Buku Pedoman, "Pembiayaan," h. 1.

${ }^{78}$ Majelis Ulama Indonesia, "Fatwa," h. 55.

${ }^{79}$ Buku Pedoman, "Pembiayaan," h. 1.

${ }^{80}$ Muhammad Syafi'i Antonio, Bank Syari'ah: Dari Teori ke Praktek (Jakarta: Gema Insani Press, 2001), h. 94.

${ }^{81}$ Berbagai model jaminan yang umumnya dapat diminta oleh pihak bank dideskripsikan secara variatif dalam contoh-contoh, yang meliputi; a) cek yang belum ditandatangani dan belum diberi tanggal diserahkan oleh nasabah kepada bank. Nilai cek akan setara dengan nilai investasi bank dalam musyârakah. Bank tidak akan menggunakan cek kecuali jika pihak mitra melakukan pelanggaran klausul kontrak, b) nota dan faktur penjualan barang musyârakah, yang berupa pembayaran yang ditangguhkan, harus disimpan pada bank. Jika para debitur (pihak ketiga) gagal membayar barang, bank akan dapat mengumpulkan utang baik dengan mengurangi rekening bank mereka atau dengan cara yang lain. Beberapa bank menyaratkan mitra untuk menitipkan 
Selain ketentuan di atas, jangka waktu juga menjadi persyaratan yang harus tertuang dalam kontrak musyârakah. Karena kebanyakan musyârakah, khususnya musyârakah dagang, adalah kontrak yang bersifat jangka pendek, dan untuk tujuan yang spesifik, maka kontrak musyârakah menetapkan jangka waktunya. ${ }^{82}$ Jika jangka waktu yang ditetapkan dalam kontrak tidak mencukupi, maka jangka waktu ini dapat diperpanjang melalui kesepakatan kedua pihak. Musyârakah dapat dihentikan dengan kesepakatan kedua pihak dengan syarat bahwa nasabah membayar seluruh tanggung jawab yang ditimbulkan oleh penghentian itu kepada bank. Menurut Jordan Islamic Bank, bank dapat menuntut pembekuan musyârakah jika dipandang oleh bank bahwa keberlanjutan musyârakah mereka adalah sia-sia, atau jika nasabah melanggar salah satu syarat kontrak. Bank dapat melakukan penghentian ini tanpa suatu pemberitahuan atau proses hukum.

Bank syariah menyadari pentingnya nilai waktu pada uang dan dalam pelaksanaan musyârakah-nya ia menuntut agar nasabah membayar bagian laba bank plus modalnya tepat pada waktu yang telah ditetapkan dalam kontrak. Dalam hal adanya penunggakan, bagian-laba nasabah, yang diberikan sebagai suatu biaya manajemen, dapat dikurangi. Dengan cara yang sama, jika nasabah membayar seluruh hutang sebelum jatuh tempo, bagian laba yang diberikan sebagai biaya bisa dinaikkan.

Kedua, Pembagian Laba dan Rugi. Dalam pembagian laba kongsi musyârakah, bankbank Islam tidak menganut pola nisbah yang seragam. Variasi model pembagian laba lazimnya tergantung kepada porsi peran mitra dalam mengelola proyek, dan volume modal yang dikeluarkan oleh mitra dan bank. ${ }^{83}$ Porsi laba bagi mitra cukup variatif dari satu musyârakah ke musyârakah

cek sebagai jaminan kepada bank sebanyak nilai penjualan barang kepada pihak ketiga. Jika pihak ketiga tidak membayar, bank dapat mencairkan cek tersebut dan, karena itu, bank secara esensial telah memperoleh pembayaran dari pihak mitra, c) bank memiliki hak untuk menahan saldo tunai, dokumen atau surat dagang milik mitra yang dititipkan kepada bank, dalam hal jika mitra tidak dapat membayar saham bank pada waktunya, d) bank menganggap dirinya sebagai pemilik barang musyârakah mulai saat pembelian barang sampai barang tersebut terjual kembali, atau e) dalam hal barang musyârakah terjual dengan pembayaran tunda kepada pihak ketiga, bank memiliki hak untuk menuntut agar mitra menjadi penjamin dan memberikan jaminan mutlak atas utang yang dimiliki pihak ketiga. Lihat Saeed, Islamic Banking, h. 66-67. Dengan berbagai model jaminan di atas, orang mungkin akan heran dan akan bertanya jika hal tersebut benar-benar sebuah kemitraan, seperti yang dibahas dalam fikih, apakah bank masih dipandang memiliki tanggung jawab moral dengan melemparkan seluruh tanggung jawab semacam itu kepada mitranya. Pertanyaan itu sebenarnya merupakan kritik tajam terhadap perbankan syariah.

${ }^{82}$ Buku Pedoman, "Pembiayaan," h. 1.

${ }^{83}$ Untuk pembiayaan musyârakah (dagang), misalnya, IIBID menawarkan pembagian laba musyârakah sebelum dipotong pajak sebagai berikut: (i) sekian persen untuk si mitra atas kerjanya dalam membeli dan menjual, menyimpan, dan penagihan hutang-hutang yang terkait dengan musyârakah, (ii) sekian persen untuk bank atas pengawasan dan manajemennya, dan (iii) sekian persen bagi modal yang diberikan kepada kongsi (sesuai dengan rasio modal yang diberikan oleh masing-masing pihak). Banque Misr (cabang syariah) menyatakan bahwa laba bersih akan dibagikan dengan cara berikut: (i) sekian persen untuk bank atas layanan perbankannya, dan (ii) sekian persen untuk si mitra atas pemasaran barang dan manajemen. Sekian persen dari saldo akan dialokasikan untuk bank dan mitranya. Dasar pembagian laba, menurut praktik Faisal Islamic 
yang lain dan tergantung kepada porsi kerja dan tingkat keahlian mereka. Keberbedaan ini dipahami bahwa semakin besar jumlah kerja yang dikeluarkan dan semakin tinggi tingkat keahlian pihak mitra, maka semakin tinggi persentase yang diperoleh. Dalam kasus Faisal Islamic Bank di Mesir, suku persentase ini berkisar antara dua puluh sampai enam puluh persen laba. Sedangkan di Tadamon Islamic Bank, Sudan, tinggi rendahnya bagian laba pihak mitra atas manajemennya didasarkan pada tingkat pekerjaan dan durasi penyelesaian kemitraan. Persentasenya berkisar antara lima puluh dan empat puluh persen. Jika ada kerugian di akhir musyârakah, yang tidak diakibatkan oleh salah-urus atau salah-guna atau pelanggaran terhadap klausul kontrak oleh pihak mitra, kerugian akan ditanggung bersama oleh kedua pihak menurut proporsi modal yang mereka berikan. Namun dalam kasus kerugian yang diakibatkan oleh salah-guna atau salah-urus dan pelanggaran terhadap klausul kontrak oleh si nasabah, maka nasabah sendirilah yang bertanggung jawab atas kerugian.

Pembahasan di atas menunjukkan bahwa kemitraan musyârakah digunakan dalam perbankan syariah dalam berbagai jenis, tetapi jenis kemitraan yang paling populer dan banyak digunakan adalah kemitraan musyârakah dagang yang berjangka pendek, meskipun jenis-jenis lain masih tetap digunakan. Dalam pembiayaan musyârakah, baik bank maupun nasabah sama-sama memberikan modal, dan banklah yang mendiktekan bagaimana musyârakah akan dijalankan untuk menjamin bahwa bank menerima modal awalnya ditambah dengan keuntungan atas modal (laba). Bank juga menuntut aneka macam jaminan untuk melindungi kepentingannya di dalam kongsi dan tampak bahwa bank berusaha menimpakan seluruh risiko yang terkait dengan manajemen musyârakah kepada mitranya. Bank juga menetapkan batas waktu musyârakah. Dari data deskriptif tersebut tidak tampak adanya metode yang seragam dalam pembagian laba dan rugi di kalangan bank syariah, meskipun metode-metode yang digunakan oleh berbagai bank terdapat kemiripan.

\section{Penutup}

Dari uraian di atas, dapat disimpulkan bahwa musyârakah dalam praktik perbankan syariah tidak dikonstruk melalui fikih an sich. Bukan berarti menyimpang sama sekali, tetapi praktiknya telah diadaptasikan dengan situasi dan kondisi riil. Adaptasi sebagian praktik perbankan itu bukan tanpa dasar melainkan didasarkan pada fikih lokal, yang kalau di Indonesia dikenal dengan KHI atau fatwa MUI.

Dalam fikih klasik, ulama sepakat bahwa jaminan, misalnya, tidak perlu mewujud

Bank, adalah sebagai berikut: (i) laba didefinisikan sebagai laba bersih setelah dikurangi dengan seluruh biaya, dan (iii) sekian porsi dari laba ini akan diberikan kepada mitra atas jasa dan kerjanya (atau yang dikenal sebagai biaya manajemen). Saldo dibagikan antara bank dan mitranya. Dalam kasus mengalami kerugian, rugi dibagi sesuai dengan proporsi modal masing-masing. Berbeda dengan Jordan Islamic Bank. Bank Jordan ini tidak menyatakan adanya ketentuan sekian persen pun untuk manajemen. Ia hanya menyatakan bahwa laba bersih akan dibagi antara bank dan mitranya, sesuai dengan kesepakatan atas rasio dalam kontrak musyârakah. Lihat Saeed, Islamic Banking, h. 68. 
dalam kontrak musyârakah, karena, menurutnya, mitra adalah orang yang dipercaya, dan atas dasar "kepercayaan" ini, maka mitra yang satu tidak dapat menuntut jaminan dari mitra yang lain. Namun fikih lokal, misalnya melalui konsesi fatwa MUI, memberikan kelonggaran kepada bank Islam mensyaratkan mitranya untuk memberikan jaminan guna mereduksi risiko dalam pembiayaan musyârakah, bahkan dapat mengkonstruk dua kemaslahatan, yaitu kemaslahatan bagi bank dan kemaslahatan bagi nasabah.

Kemaslahatan bank terwujud karena risiko yang sengaja dibangun oleh nasabah bisa diproteksi dan minimal dapat direduksi. Sedangkan kemaslahatan bagi nasabah adalah bahwa dengan jaminan itu, nasabah akan mampu menghilangkan atau, paling tidak, dapat memperkecil kemungkinan melakukan kelalaian dan penyimpangan dalam kegiatan musyârakah yang memang tidak dibenarkan dan tidak dikehendaki oleh Islam.

\section{Pustaka Acuan}

Alam, Mohammad Manzoor. Perspectives on Islamic Economics. New Delhi: Institute of Objective Studies, 1996.

Ali, Atabik dan Ahmad Zuhdi Muhdor. Kamus Kontemporer Arab-Indonesia. Yogyakarta: Multi Karya Grafika, 2001.

Antonio, Muhammad Syafi'i. Bank Syariah: dari Teori ke Praktek. Jakarta: Gema Insani Press, 2001.

Anwar, Syamsul. Hukum Perjanjian Syariah: Studi tentang Teori Akad dalam Fikih Muamalat. Jakarta: RajaGrafindo Persada, 1997.

Arifin, Zainul. Dasar-dasar Manajemen Bank Syariah. Jakarta: AlvaBet, 2003.

Buku Pedoman Pembiayaan Kecil Syariah pada BNI Syariah. "Pembiayaan_Musyârakah," 2007.

Chapra, M. Umer. Towards a Just Monetary System. London: the Islamic Foundation, 1985.

Dahlan, Abdul Aziz (ed.). Ensiklopedi Hukum Islam. Jakarta: Ichtiar Baru van Hoeve, 1996.

Dewan Syariah Nasional Majelis Ulama Indonesia. "Fatwa Dewan Syariah Nasional No.

08/DSN-MUI/IV/2000 tentang Pembiayaan Musyârakah," dalam Himpunan Fatwa Dewan Syariah Nasional. Jakarta: DSN-MUI \& BI, 2003.

Fikrî, 'Alî. Al-Mu 'âmalât al-Mâdiyah wa al-Adabîyah. Kairo: Mushtafâ al-Bâb al-Halibî, t.t. Glasse, Cyril. The Concise Encyclopedia of Islam. London: Stacy International, 1989.

Houtsma, M. Th., et al. E.J. Brill's First Encyclopaedia of Islam 1913-1936, Vol. III. Leiden: E.J. Brill, 1987.

Islahi, A.A. Konsep Ekonomi Ibnu Taimiyah, terj. Anshari Thayib. Surabaya: Bina Ilmu, 1997. Karim, Helmi. Fikih Muamalah. Jakarta: RajaGrafindo Persada, 1997.

Al-Kâsânî, Imâm 'Alâ' al-Dîn Abî Bakr ibn Mas'ûd. Badâ'i' al-Shanâ'i' fî Tartîb al-Syarâ'i'. Beirut: Dâr al-Fikr, 1996. 
Khan, Muhammad Akram. An Introduction to Islamic Economics. Islamabad: International Institute of Islamic Thought, 1994.

Khan, M. Fahim. Essays in Islamic Economics. Leicester, UK: the Islamic Foundation, 1995.

Al-Khayyâth, 'Abd al-'Azîz 'Izat. Al-Syarikât fî al-Syarî'ah al-Islâmîyah wa al-Qânûn alWadh'̂, Juz I. Beirut: Mu'assasah al-Risâlah, 1994.

Lewis, Mervyn K. dan Latifa M. Algaoud. Perbankan Syariah: Prinsip, Praktek dan Prospek, terj. Burhan Wirasubrata. Jakarta: Serambi Ilmu Semesta, 2003.

Mujieb, M. Abdul, Mabruri Tholhah, Syafi'ah AM. Kamus Istilah Fikih. Jakarta: Pustaka Firdaus, 1994.

Munawwir, Ahmad Warson. Al-Munawwir: Kamus Arab-Indonesia. Surabaya: Pustaka Progresif, 1997.

Mûsâ, Muhammad bin Ibrâhîm. Syarikât al-Asykhâsh bayna al-Syarî’ah wa al-Qânûn. t.t.p.: Jâmi'ah al-Imâm Muhammad bin Mas'ûd al-Islâmîyah, 1401 H.

Naqvi, Syed Nawab Haider. Ethics and Economics: An Islamic Systems. U.K.: The Islamic Foundation, t.t.

Nasution, Harun (tim). Ensiklopedi Islam Indonesia. Jakarta: Djambatan, 1992.

Nomani, Farhad and Ali Rahnema. Islamic Economic Systems. London \& New Jersey: Zed Books Ltd., 1994.

Pasaribu, Chairuman dan Sahrawardi K. Lubis. Hukum Perjanjian dalam Islam. Jakarta: Sinar Grafika, 1996.

Qudâmah, Ibn. Mughnî al-Muhtâjj, Jilid V, (t.t.p: t.p, t.t).

Qudâmah, Ibn. Al-Kâfi fî Fiqh al-Imâm Ahmad ibn Hanbal, (t.t.p: t.p, t.t).

Qureshi, Anwar Iqbal. Islam and the Theory of Interest. Lahore: Sh. Md. Ashraf, 1991.

Rahman, Afzalur. Economic Doctrines of Islam, terj. Suroyo dan Nastangin.Yogyakarta: Dana Bakti Wakaf, 1996.

Ramadan, Said. Islamic Law: the Scope and Equity. Malaysia: Muslim Youth Movement of Malaysia, 1992.

Rusyd, Ibn. Bidâyah al-Mujtahid wa Nihâyah al-Muqtashid, Juz II. Beirut: Dâr al-Jîl, 1989.

Sabiq, Sayyid. Fiqh al-Sunnah. Kairo: Dâr al-Fath li al-I'lâm al-'Arabî, 2000.

Saeed, Abdullah. Islamic Banking and Interest. Leiden: E.J. Brill, 1996.

Saleh, Nabil A. Unlawful Gain and Legitimate Profit in Islamic Law: Riba, Gharar and Islamic Banking. Cambridge: Cambridge University Press, 1986.

Al-Syawkânî, Muhammad bin 'Alî bin Muhammad. Nayl al-Awthâr: Syarh Muntaqâ alAkhbâr min Ahâdîth al-Akhyâr, juz V. Beirut: Dâr al-Jîl, t.t.

Siddiqi, Muhammad Nejatullah. "Islamic Approaches to Money, Banking and Monetary: a Review", dalam Muhammad Ariff (ed.), Monetary and Fiscal Economics of Islam. Jeddah: International Centre for Research in Islamic Economics, 1982. 
MIQOT Vol. XXXVI No. 1 Januari-Juni 2012

Shiddiqi, S.H. Islamic Banking: Genesis, Rationale, Evaluation and Review, Prospects and Challenges. Karachi: Royal Book Company, 1994.

Sudarsono, Heri. Bank dan Lembaga Keuangan Syariah: Deskripsi dan Ilustrasi._Yogyakarta: Ekonisia, 2004.

Uzair, M. An Outline of Interest-Free Banking. Karachi: Royal Book Company, 1978.

Al-Zuhaylî, Wahbah. Al-Fiqh al-Islâmî wa Adillatuh, Juz IV. Kairo: Dâr al-Fikr, 1989. 